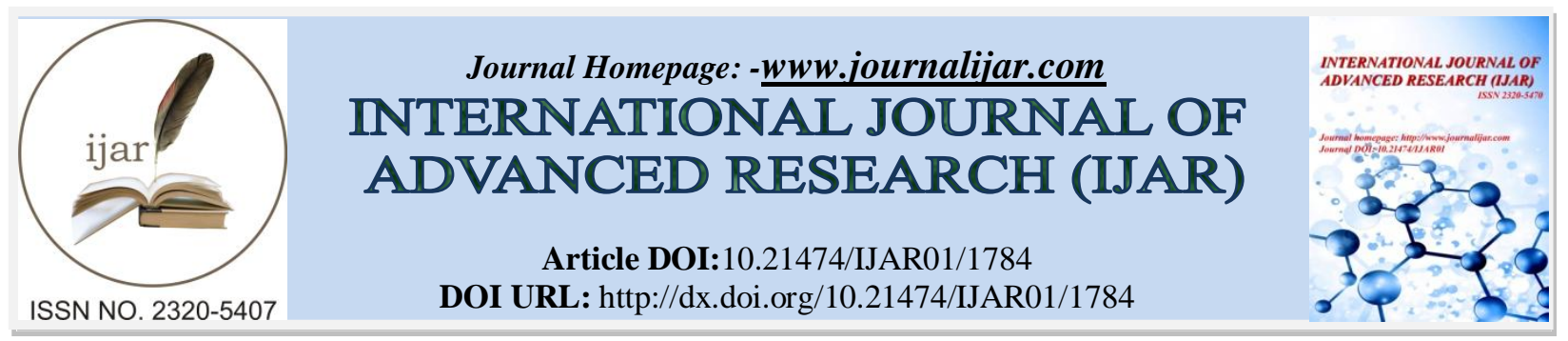

RESEARCH ARTICLE

\title{
PHYSIOLOGICAL AND OXIDATIVE STRESS BIOMARKERS IN THE FRESHWATER CATFISH(CLARIAS GARIEPINUS) EXPOSED TO PENDIMETHALIN-BASED HERBICIDE AND RECOVERY WITH EDTA.
}

Samir A. M. Zaahkook, Hesham G. Abd El- Rasheid, Mohamed H. Ghanem and Salah M. AL-Sharkawy. Zoology Department, Faculty of Science, Al-Azhar University, Cairo, Egypt.

\section{Manuscript Info}

Manuscript History

Received: 12 August 2016

Final Accepted: 23 September 2016

Published: October 2016

Key words:-

Pendimethalin;EDTA;Clarias gariepinus; haematology; liver

functions; Heart functions tests; glucose;

oxidative stress; antioxidants

biomarkers.

\section{Abstract}

The present study was planned aiming to investigate the effects of Pendimethalin herbicide exposure on haematological, biochemical, oxidative stress and antioxidant biomarkers in the tissue liver of catfish and recovery effects of ethylene diamine tetra acetic acid on the degree of Pendimethalin sublethal toxicity for 42 day. The experiment was carried out on (100)catfish that randomly divided in to nine equal groups with fife replicates: The 1st group kept as control, the $2^{\text {nd }}$ group and $3^{\text {rd }}$ group exposed to $(5 \%)$ and $(10 \%)$ of Pendimethalin for 7 days, the $4^{\text {th }}$ and $5^{\text {th }}$ group exposed to $(5 \%)$ and $(10 \%)$ of Pendimethalin and recovery with EDTA for 7 day, the $6^{\text {th }}$ and $7^{\text {th }}$ exposed to $(5 \%)$ and $(10 \%)$ of Pendimethalin for 21 day, while the $8^{\text {th }}$ and $9^{\text {th }}$ group exposed to $(5 \%)$ and $(10 \%)$ of Pendimethalin and recovery with EDTA for 14 day.

Abnormal behavioral responses of the catfish and the toxic symptoms of pendimethalin exposure are described. Acute exposure to pendimethalin induced leukocytosis, hyperglobulinemia, hyperglycemia and increased lipid profile.Moreover, pendimethalin increased lipid peroxidation (LPO) and decreased levels of reduced glutathione and antioxidant enzymes; superoxide dismutase, catalase, and glutathione reductase in the liver tissue. We conclude that although pendimethalin is moderately toxic and cause significant deleterious effects on fish and aquatic invertebrates, it does not cause renal toxicity. However, this herbicide pollutant induces major disturbances to the antioxidant system; induction of oxidative stress and LPO is the proposed toxicodynamic pathway for such stress. Toxicity with Pendimethalin (Stomp) can end up in humans through thefood chain. However, fish recovered with EDTA exhibited protective effect by minimizing the Pendimethalin-induced toxicity, through measured values more or less similar to the control group fish.

Copy Right, IJAR, 2016,. All rights reserved.

\section{Introduction:-}

The pollution of rivers, lakes, and canals by chemical substances of anthropogenic origin may result in water that is unsuitable for household use, irrigation, and fish cultivation, and may negatively impact the animal communities 
living in these bodies of water in addition to the increasing uses of pesticides, which include insecticides, herbicides and fungicides, is intensifying worldwide pollution risk (Malins and Ostrander, 1991; Moraes, et al., 2007; Rudneva, 2007 and El-Sayed, et al., 2013).

Water pollution is one of the principal environmental and public health problems that Egyptian River Nile are facing and the contamination of fresh water with a wide range of pollutants has become a matter of concern over the last few decades (Canli and Kalay, 1998., Anwar, 2003 and Vutkuru, 2005). In which the Nile represents the main freshwater resource for the country, meeting nearly all demands for drinking water, irrigation, and industry. During its transit through Egypt, the river Nile receives numerous non-point and point source discharges(Osman, et al ., 2010). The severity of herbicides hazards is much pronounced in the third world countries in which the use of this environmental pollutants reported to accumulate in bodies of fishes and has dangerous effects on human health through the food chain, so these pollutants is toxic and may be mutagenic or carcinogenic to human (Porte and Albaiges, 1994; Jacobs, et al., 2002).

Fishes exposed to toxicants undergo stress, which is a state of re-established homeostasis, a complex suite of maladaptive responses (Chrouses, 1998 ;Olufayo and Alade, 2012 ). Under stress, physiological and biochemical responses may be compromised, becoming detrimental to the fish's health and well-being at which point the fish is termed distressed (Barton and Iwama, 1991).

Studieson the toxicity and effects of pendimethalin herbicideson fish and aquatic organisms are limited (Ahmed and Moustafa, 2010; Abd-algadiret al., 2011 and El-Sharkawyet al., 2011).It is a systemic toxicant rated as moderately toextremely toxic to fish and aquatic organisms, and whichcan give rise to long-lasting metabolites.

Pendimethalin contains dinitroanilines, which can reportedly facilitate the formation ofcarcinogenic nitrosamines, a group C carcinogen (possiblehuman carcinogen) (US EPA, 1997).Pendimethalin is the active ingredient of many commercially herbicides formulations which including the following :Stomp ${ }^{\circledR} 50 \%$, Stomp ${ }^{\circledR} 45.5 \%$, Stomp ${ }^{\circledR} 33 \%$, Prowl $^{\circledR}$, Squadron ${ }^{\circledR}$, prowl $\mathrm{H}_{2} \mathrm{O}$ and Pendimax $3^{\circledR}$ in Egypt, while in Australia, China, Canada, Korea, Philippines, New Zealand, Europe and the USA is Stomp ${ }^{\circledR}$, Pendimethalin ${ }^{\circledR,}$ Herbadox $^{\circledR,}$, and AC $92553^{\circledR}$ USEPA, (1985) and Moustafaet al., (2016). The determination oftoxicity is essential for assessing the sensitivity of animals tospecific toxicants, for evaluating the degree of damage tospecific organs, and for assessing the extent of ensuingbehavioral, physiological, and biochemical disorders.

Catfish (Clarias gariepinus) is of great commercial importance and it is the most common fresh water fish widely consumed in Egypt and Africa Farombi et al., (2008).It can therefore be a good model to study responses to various environmental contaminants due to two reasons. First this species of fish exhibits anatomical and physiological changes at the level of both respiratory and circulatory systems, owing to the presence of a ramifying organ in the peribranchial cavity for air-breathing. Secondly, this specie apart from the fact that it is found in Africa rivers also lives in temporary puddles forming in desert areas after rainy inundation, in which a large amount of pollutant rapidly accumulate Olaifa $\boldsymbol{e t}$ al., (2004). Catfish and aquatic animals are exposed to Pendimethalin via three ways, the first is dermally through direct absorption via the skin by swimming in the herbicide-contaminated water, the second way is breathing via direct uptake the herbicides through the gills during the respiration process, the last way is orally via drinking the herbicides- contaminated water of feeding on herbicides- contaminated preys ( Hardersen and Wratten, 1998).

Knowledge of the haematological characteristics is an important tool that can be used as an effective and sensitive index to monitor physiological and pathological changes in fishes and the exposure of chemical pollutants can induce either increase or decrease in haematological level and the lymphocytes were the most abundant type of leucocyte in the peripheral blood of $C$. gariepinus exposed to paraquet herbicide this was followed by the neutrophils, while the least abundant type of leucocyte was the eosinophils (Alohan, et al., 2014 and Nwani, et al., 2015 ).Erhunmwunseand Ainerua,(2013) studded the haematological profile of Juvenile catfish (Clarias gariepinus). Hematological indices and leucocyte differential count) were measured in blood samples of African catfish and said that Knowledge of these haematological characteristics is an important tool that can be used as an effective and sensitive index to monitor physiological and pathological changes in fishes.

Because fish are able to uptake and retain different xenobiotic compounds from water via active or passive processes, biochemical investigations have been routinely used for monitoring the environmental exposure of fish to 
contaminant, in laboratory and field studies, which are sensitive for the detection of the potential adverse effects of xenobiotics released into the environment (Almeida, et al., 2002; Sancho, et al., 2003; Shallaja and D'Silva, 2003).

The liver plays an important role in many metabolic processes such as glycemic control, detoxification of xenobiotic, synthesis of lipoproteins, hormones and enzymes (Klip and Vranic, 2006).The aquatic ecosystems are under the pressure of complex mixtures of contaminants released in the environment due to various human activities exert multiple stress effects; they originate from miscellaneous sources such as chemical and drug manufacture, domestic sewage, polymer and petrochemical-based industries, oil refineries, mining, glass blowing, battery manufacture and many others (Widianarkoet al., 2000; Ueno et al., 2004 and Huskaet al., 2008).Environmental contaminants such as herbicides, heavy metals and insecticides are known to modulate antioxidant defensive systems and to cause oxidative damage in aquatic organisms by ROS production. Thus the activity of antioxidant enzymes and the occurrence of oxidative damage have been proposed as indicators of pollutant-mediated oxidative stress(Li et al., 2003; Hermes-Lima, 2004 and Monterioet al., 2006). Moreover the release of ROS by phagocytic cells can be stimulated after pollutant exposure have been shown to result in increasing ROS production in subcellular fractions of various tissues, especially the liver, kidney and gills(Fatima et al., 2000; Livingstone, 2001; Schmiederet al., 2003and Moustafaet al., 2016).Oxidative stress is one of the major factors in the pathogenesis of liver disease. Recent evidence implicates the role of oxidative stress in the pathogenesis and/or complications of these disorders (Shibata, and Kobayashi 2008; Kadenbach, et al., 2009). Fishare endowed with antioxidant defense pathways for neutralizingROS; these pathways involve antioxidant enzymessuch as superoxide dismutase (SOD), catalase (CAT), andglutathione reductase (GR), as well as non-enzymatic antioxidantssuch as reduced glutathione (GSH) (Glusczaket al., 2006; Modesto and Martinez, 2010 and EL-Sayed et al., 2013).

In standard medical practice, certain medications (also known as 'chelants' [key-lints]) are used in specific situations to help remove high levels of certain metals from the body. The chelators bind to these metals in the blood and some body tissues causing them to be more quickly eliminated in the urine or stool. Whether the chelation medication is swallowed, or injected into the muscle or vein, depends on the type of chelation medication used and the medical situation of the patient being treated. Some practitioners of complementary medicine use medications or natural products, labeled as chelators, to treat a variety of chronic medical conditions. Chelation therapy has been scientifically proven to be beneficial treatment for poisoning (high exposure) from metals such as lead, mercury, and arsenic when carried out under competent medical supervision. It is also used to treat large amounts of iron or copper that accumulates in the body due to certain diseases according toAmerican academy of clinical toxicology 2012.EDTA is achelating agents belong to the group of Aminopolycarboxylic acids. Poison Centers list two types of EDTA, namely Na-CaEDTA(calcium-disodium ethylene diamine tetra acetic acid and Na-EDTA (ethylenediaminetetraacetic acid, also refered to as Disodiumedetat) as antidotes for lead, chromium, cobalt, vanadium, zinc, cadmium and radioactive metals. The California Poison Control System lists Ca-EDTA (brandnameVersenate) for heavy metal poisoning(Blaurocket al., 2014).

\section{Materials and methods:-}

Chemicals and Reagents:-

Commercially available pendimethalin-based formulation (StompVR50\% EC, BASF PLC) was used in this study. It is an orange-yellow emulsive herbicide, whose active ingredient is the pendimethalin [C13H19N3O4; N-(1ethylpropyl)- 3,4-dimethyl-2,6-dinitrobenzenamine] of dinitroaniline family. 25_C and aqueous photolysis of 60 days (US EPA, 1997).

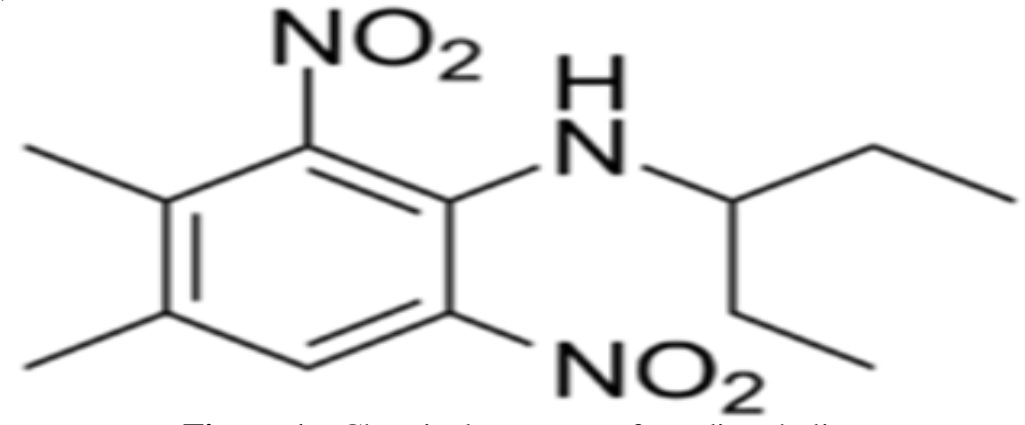

Figure 1:- Chemical structure of pendimethalin. 


\section{Animals andExperimental design:-}

All animal-related procedures were carried out in accordance with the Ethical Committee of UAL-Azhar University.

A total number of 100 of live catfish $C$. gariepinus with average body weight $250 \pm 50 \mathrm{~g}$ at the beginning of the experimental were obtained from Abbasa fish farm, Central Laboratory of Aquaculture (CLAR), El-Sharkya governorate, Egypt. They were transferred to the laboratory of Fishes in the animal house, Zoology Department, Faculty of Science at AL-Azhar University . About (100) African catfish average weight around between $(250 \pm 25 \mathrm{~g})$ at the beginning of the experiment were divided into (9) main groups according to the treatment, recovery and requirements of the experiment.

100 African catfish were randomly divided into nine equal groups and labeled as groups 1,2,3,4,5,6,7,8 and 9, each group contain 5 fishes as the following:

* Group 1: Control fishes, fish of this group were neither treated nor recovery by EDTA.

* Group 2: Fishes were treated with $5 \%$ of pendimethalin herbicide for 7 days.

- Group 3: Fishes were treated with 5\% of pendimethalin herbicide for 7 days and recovery with ethylene diamine tetra acetic acid ( EDTA) $0.3 \mathrm{~g} / \mathrm{L}$ for 7 days .

* Group 4: Fishes were treated with $10 \%$ of pendimethalin herbicide for 7 days.

* Group 5: Fishes were treated with $10 \%$ of pendimethalin herbicide for 7 days and recovery with ethylene diamine tetra acetic acid ( EDTA) $0.3 \mathrm{~g} / \mathrm{L}$ for 7 days.

* Group 6: Fishes were treated with $5 \%$ of pendimethalin herbicide for 21 days .

- Group 7: Fishes were treated with 5\% of pendimethalin herbicide and recovery with ethylene diamine tetra acetic acid ( EDTA) $0.3 \mathrm{~g} / \mathrm{L}$ for 21 days .

* Group 8: Fishes were treated with $10 \%$ of pendimethalin herbicide for 21 days .

* Group 9: Fish were treated with $10 \%$ of pendimethalin herbicide and recovery with ethylene diamine tetra acetic acid ( EDTA) $0.3 \mathrm{~g} / \mathrm{L}$ for 21 days .

\section{Sample preparation:-}

$>$ All samples should be prepared before reconstitution of the reagents.

$>$ 1. Wash the liver tissue in physiological saline solution, $\mathrm{pH}$ 7.4.

$>$ 2. Homogenize the tissue in $10 \mathrm{ml}$ cold phosphate buffer $\mathrm{pH}$ 7.4.

$>$ 3. Centrifuge the homogenate tissue at $4,000 \mathrm{rpm}$ for 15 minutes at $4{ }^{\circ} \mathrm{C}$.

$>$ 4. Collect supernatant, If not assayed immediately store the supernatant at $-80^{\circ} \mathrm{C}$.

Blood and liver tissue samples were obtained from fish of the studied groups at 1, 2, 3, 4, 5 and 6, 7, 8 and 9groups of acute and chronic exposure, for the investigation of the haematological, biochemical parameters, antioxidant and oxidative stress.

\section{Haematological examination:- \\ Blood sampling collection:-}

Hematological examination of the catfishes were performed on surviving fishes. The body surface were cleaned and blotted dry with adsorbent paper. A first blood samples, collected from the caudal vein using disposable 3-c syringes and 21-gauge needles, were transferred into vacuette tubes containing $\mathrm{k}_{2}$ EDTA solution(greiner bio-one company) as an anticoagulant for determination of red blood corpuscles (RBCs), platelets white blood cells count and deferential leucocyte count ( lymphocyte, neutrophil, monocyte, eosinophil and basophil), hemoglobin concentration and percentage $(\mathrm{Hb} \%)$, packed cell volume (PCV), mean corpuscle volume (MCV), mean corpuscle hemoglobin $(\mathrm{MCH})$ and mean corpuscle hemoglobin concentration (MCHC) were estimated by cell blood counterLabomed, Inc. SK9000 Sino thinker in Zoology dep faculty of Scienceat AL-Azhar Universityand the result confirmed by Sysmex kx- 21n automated hematology analyzer.

\section{Biochemical examination:-}

The second blood samples were collected from the fish caudal vein using plastic syringes in dry sterilized vials without any anticoagulants. The samples were allowed to clot at room temperature and centrifuged, then serum was separated for determination ofthe following parameters serum levels of transaminases, alkaline phosphatase, total protein, albumin and globulin were estimated using kits from Elitech diagnostic Comp. France. The concentrations of transaminases (ASAT and ALAT) were determined using the method of Bergmeyeret al. (1986). Serum ALP 
was determined according to the method described by the German Society for Clinical Chemistry (1972). Serum total protein was determined according to the method described by Gornalet al (1949). Serum albumin was determined according to the method described by Doumaset al (1971).Plasma glucose level was determined according to the method of Dods (2003) using kit from Elitech diagnostic Co. France. Serum Gamma Glutamate Transaminase ( $\gamma$-GT)is determined according to the method of (Rosalki, et al., 1971) using a commercial kit derived from Randox comp. Lactate dehydrogenase (LDH activity was assayed using commercial kit from (Spainreact, Spain) according to the method of (Young and Friedman, 2001).CPK (Creatinephospho Kinase) is mainly found in all muscle and brain tissueusing kit from Elitech diagnostic Co. France CPK level was determined according to the German Society for Clinical Chemistry (1972).

\section{Lipid peroxidation and oxidative stress:-}

Sample preparation:-

All samples should be prepared before reconstitution of the reagents.

1. Wash the liver tissue in physiological saline solution, $\mathrm{pH}$ 7.4.

2. Homogenize the tissue in $10 \mathrm{ml}$ cold phosphate buffer $\mathrm{pH}$ 7.4.

3. Centrifuge the homogenate tissue at $4,000 \mathrm{rpm}$ for 15 minutes at $4{ }^{\circ} \mathrm{C}$.

4. 4. Collect supernatant, If not assayed immediately store the supernatant at $-80^{\circ} \mathrm{C}$.

Blood samples were collected without anti-coagulants and centrifuged at 4000 r.p.m for 10 minutes to prepare serum. The sera were frozen at $-20^{\circ} \mathrm{C}$ until used.

Lipid peroxidation product, malondialdehyde (MDA), was measured by thiobarbituric acid (TBARS) assay, which is based on the determination of malondialdehyde (MDA), an end product of lipid peroxidation, which can react with thiobarbituric acid to yield a pink colored complex exhibiting a maximum absorption at 534nm (Yoshioka et al., 1979). Glutathione was determined according to the method of Beutleret al. (1963). This method is based on the reduction of 5, 5 dithiobis (2 - nitrobenzoic acid) (DTNB) with glutathione (GSH) to produce a stable yellow compound. The reduced chromogen directly proportional to GSHconcentration and its observance can be measured at $412 \mathrm{~nm}$. The activities of CAT and SOD were estimated using kits from bio-diagnostic for research kits, Egypt. The SOD activity was assayed according to the procedure described by Yoshioka $\boldsymbol{e t}$ al., (1979) and the assay of CAT activity was determined according to the method of Aebi (1984). Glutathione reductase(GR) activity of the tissue homogenate was determined according to the method of Goldberg and Spooner, (1983). Other reagents was performed according to the instruction manual of reagent kits purchased from Biodiagnostic or / and Biotechnology Co., Dokki, and Giza, Egypt.

The statistical package for social sciences SPSS/PC computer program (version 20) was used for statistical analysis of the results. Data were analyzed using one-way analysis of variance (ANOVA). The data were expressed as mean \pm S.E. Differences were considered statistically significant at $(\mathrm{P}<0.05)$.

\section{Results:-}

Data found in table (1) showed that slightly a significant increase $(\mathrm{P}<0.05)$ in red blood corpuscles $(\mathrm{RBCs})$ in catfishes treated with 5\% of Pendimethaline for 7 days only, when compared with the control group. In addition to the catfishes treated with Pendimethaline at concentration 5\% and 10\% and recovery with EDTA for 7 days showed a significant decrease $(\mathrm{P}<0.05)$ in $\mathrm{RBCs}$ when compared with treated groups.

Data found in table (1) showed that a significant increase $(\mathrm{P}<0.05)$ in white blood cells $(W B C s)$ count in catfishes treated with concentration $5 \%$ and $10 \%$ of pendimethaline for 7 and 21 days when compared with the control group. While, catfishes treated with concentration $5 \%$ and $10 \%$ of pendimethaline and recovery with EDTA for 7 days and 21 day observed a significant decrease $(\mathrm{P}<0.05)$ in total leucocyte count $(\mathrm{TLC})$ when compared with treated groups.

Platelets found in table (1) revealed a significant decrease $(\mathrm{P}<0.05)$ in catfish treated with $5 \%$ of pendimethaline for 7 and 21 days when compared with the control group. While insignificant decrease in platelets count was recovered in catfishes treated with concentration $10 \%$ of pendimethalin for 7 and 21 day when compared with treated groups. From the other point of the view the catfishes treated with 5\% and $10 \%$ of pendimethaline and recovery with EDTA for 7 and 21 days showed insignificant increase in platelets when compared with treated groups. 
Statistical data of haemoglobin in table (1) observed a significant decrease in catfishes treated with concentration 5 $\%$ of pendimethaline for 21 days when compared with the control group, also the date demonstrated a significant decrease the catfish treated with 5\% of pendimethaline and recovery with EDTA for 7 days when compared with treated groups, while the other data reported that asignificant increase in the catfishes treated with concentration 5\% of pendimethaline and recovery with EDTA for 21 days when compared with treated groups.

Table 1:- Mean values of RBCS,WBCS,PLATS and HB on catfish (Clarias gariepinus) intoxicated with pendimethalin (stomp) and recovery with EDTA at different interval periods.

\begin{tabular}{|c|c|c|c|c|c|c|c|c|c|c|}
\hline \multirow[t]{3}{*}{ Parameters } & \multicolumn{10}{|c|}{ Groups } \\
\hline & & \multirow{2}{*}{$\begin{array}{c}\text { Period } \\
\text { Control }\end{array}$} & \multicolumn{4}{|c|}{7 days } & \multicolumn{4}{|c|}{21 days } \\
\hline & & & $\begin{array}{c}\text { Stomp } \\
(5 \%)\end{array}$ & $\begin{array}{c}(5 \%) \\
\text { Recovery }\end{array}$ & $\begin{array}{l}\text { Stomp } \\
(\mathbf{1 0 \% )})\end{array}$ & $\begin{array}{c}(\mathbf{1 0 \% )}) \\
\text { Recovery }\end{array}$ & $\underset{5 \%}{\text { Stomp }}$ & $\begin{array}{c}(5 \%) \\
\text { Recovery }\end{array}$ & $\begin{array}{l}\text { Stomp } \\
(\mathbf{1 0 \%})\end{array}$ & $\begin{array}{c}(10 \%) \\
\text { Recovery }\end{array}$ \\
\hline \multirow{3}{*}{$\begin{array}{l}\text { RBCs } \times \\
10^{6} \\
\left(\text { cell } / \mathbf{m m}^{3}\right)\end{array}$} & Mean & 1.9 & 1.94 & 1.80 & 2.37 & 2.25 & 1.89 & 2.01 & 1.94 & 2.29 \\
\hline & $\begin{array}{c} \pm \\
\text { S.E }\end{array}$ & $\begin{array}{c} \pm \\
0.07^{\mathrm{a}}\end{array}$ & $\stackrel{ \pm}{ \pm .06^{\mathrm{b}}}$ & $\begin{array}{c} \pm \\
0.09^{\mathrm{c}}\end{array}$ & $\stackrel{ \pm}{ \pm .12^{\mathrm{a}, \mathrm{b}}}$ & $\stackrel{\stackrel{ \pm}{\mathrm{c}, \mathrm{d}}}{0.15^{-1}}$ & $\begin{array}{c} \pm \\
0.08^{\mathrm{a}} \\
\mathrm{b}\end{array}$ & $\stackrel{ \pm}{ \pm}_{0.07^{\mathrm{a}, \mathrm{b}, \mathrm{d}}}$ & $0 . \stackrel{ \pm}{\mathrm{d}, \mathrm{e}}^{\mathrm{a}, \mathrm{b}}$ & $\underset{0.28^{\mathrm{c}, \mathrm{e}}}{ \pm}$ \\
\hline & $\%$ & 0.07 & 0.06 & 0.09 & 0.12 & 0.15 & 0.08 & 0.07 & 0.17 & 0.28 \\
\hline \multirow{3}{*}{$\begin{array}{l}\text { WBCs } \times \\
10^{3} \\
\left(\operatorname{cell} / \mathbf{m m}^{3}\right)\end{array}$} & Mean & 44.25 & 78.0 & 50.75 & 106.5 & 66.75 & 64.25 & 54.75 & 73.75 & 61.25 \\
\hline & $\begin{array}{c} \pm \\
\text { S.E }\end{array}$ & $2.57^{\mathrm{a}}$ & $\begin{array}{c} \pm \\
2.85^{\mathrm{b}}\end{array}$ & $\stackrel{ \pm}{ \pm} 1.71^{\mathrm{a}, \mathrm{e}}$ & $\stackrel{ \pm}{5.14^{\mathrm{c}}}$ & $1.32^{\mathrm{d}, \mathrm{f}}$ & $2.42^{\mathrm{d}}$ & $\begin{array}{c} \pm \\
2.03^{\mathrm{e}, \mathrm{g}}\end{array}$ & $2 . \stackrel{ \pm}{ \pm}^{\mathrm{b}, \mathrm{f}}$ & 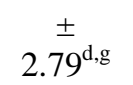 \\
\hline & $\%$ & 2.57 & 2.85 & 1.71 & 5.14 & 1.32 & 2.42 & 2.03 & 2.56 & 2.79 \\
\hline \multirow{3}{*}{$\begin{array}{l}\text { Plats } \times \\
10^{3} \\
\left(\text { cell } / \mathbf{m m}^{3}\right)\end{array}$} & Mean & 150.0 & 95.25 & 139.25 & 94.01 & 114.0 & 87.25 & 145.0 & 94.7 & 145.1 \\
\hline & $\begin{array}{c} \pm \\
\text { S.E }\end{array}$ & $\begin{array}{c} \pm \\
7.62^{\mathrm{a}}\end{array}$ & $\stackrel{ \pm}{ \pm}$ & $\begin{array}{c} \pm \\
14.8^{\mathrm{b}}\end{array}$ & $\begin{array}{c} \pm \\
10.7^{\mathrm{a}}\end{array}$ & $8.5^{\mathrm{a}, \mathrm{b}}$ & $\begin{array}{c} \pm \\
9.8^{\mathrm{b}}\end{array}$ & $\begin{array}{c} \pm \\
12.4^{\mathrm{b}}\end{array}$ & $\begin{array}{c} \pm \\
21.2^{\mathrm{a}}\end{array}$ & $\begin{array}{c} \pm \\
12.2^{\mathrm{a}}\end{array}$ \\
\hline & $\%$ & 7.62 & 13.3 & 14.8 & 10.7 & 8.5 & 9.8 & 12.4 & 21.2 & 12.2 \\
\hline \multirow[t]{3}{*}{$\begin{array}{c}\text { Hb } \\
\text { (gm) }\end{array}$} & $\begin{array}{c}\text { Mean } \\
\pm\end{array}$ & $\begin{array}{c}14.8 \\
\pm\end{array}$ & $\begin{array}{c}15.25 \\
\pm\end{array}$ & $\begin{array}{c}13.47 \\
\pm\end{array}$ & $\begin{array}{c}17.30 \\
\pm\end{array}$ & $\begin{array}{c}14.70 \\
\pm\end{array}$ & $\begin{array}{c}12.47 \\
\pm\end{array}$ & $\begin{array}{c}13.75 \\
\pm\end{array}$ & $\begin{array}{c}15.65 \\
\pm\end{array}$ & $\begin{array}{c}13.70 \\
\pm\end{array}$ \\
\hline & S.E & $\underset{\mathrm{e}}{0.71^{\mathrm{a}, \mathrm{d}},}$ & $0 . \bar{c} \bar{s}^{\mathrm{a}, \mathrm{d}}$ & $0 . \overline{8} 1^{\mathrm{c}}$ & $1 . \overline{46}^{\mathrm{b}, \mathrm{e}}$ & $0.30^{\mathrm{a}, \mathrm{d}, \mathrm{e}}$ & $0 . \overline{2}^{\mathrm{b}}$ & $0 . \overline{4} 5^{\mathrm{a}, \mathrm{c}}$ & $\underset{\mathrm{b}}{1.14^{\mathrm{a}, \mathrm{d}},}$ & $0.84^{\mathrm{b}, \mathrm{d}}$ \\
\hline & $\%$ & 0.71 & & & & & & & & \\
\hline \multicolumn{11}{|c|}{$\begin{array}{l}\text { Each value represented means of } 5 \text { records } \pm \text { S.E. } \\
\text { a,b,c,d.e means comparison between all groups which the groups have the same letter mean there is no significance } \\
\text { difference and which have different letter mean there is a significance differences. } \\
\%: \text { Percent of changes from control values. }\end{array}$} \\
\hline
\end{tabular}

Data found in table (2) showed a significant increase $(\mathrm{P}<0.05)$ in mean corpuscular haemoglobin $(\mathrm{MCH})$ in catfishes treated with concentration 5\% of pendimethaline and recovery with EDTA for 21 days when compared with the treated groups. While insignificant decrease in $\mathrm{MCH}$ value was revealed in groups treated with pendimethalin at concentration 5\% and $10 \%$ and recovery with EDTA for 7 days, also insignificant decrease in MCH value was recorded in concentration $10 \%$ for 21 day.

Mean corpuscular haemoglobin concentration $(\mathrm{MCHC})$ found in table $(2)$ observed a significant decrease $(\mathrm{P}<0.05)$ in catfishes treated with concentration $5 \%$ of pendimethaline only for 7 days and 21 days when compared with the control group. While a significant increase $(\mathrm{P}<0.05)$ in $\mathrm{MCHC}$ value was showed in catfishes treated with concentration $10 \%$ of pendimethaline and recovery with EDTA for 21 when compared with the control group. From the other hand, the catfishes treated with concentration $5 \%$ and $10 \%$ of pendimethaline and recovery with EDTA for 7 days and 21 days showed a significant increase $(\mathrm{P}<0.05)$ in $\mathrm{MCHC}$ value, except the group treated with pendimethalin and recovery with EDTA at $10 \%$ for 21 day revealed insignificant decrease in MCHC value.

Statistical data of haematocrite (Hct \%) in table (2) observed a significant increase $(\mathrm{P}<0.05)$ in catfishes treated with concentration $5 \%$ of pendimethaline for 7 days when compared with the control group, while insignificant difference in Hct value was recorded in the other groups in comparison with the control group, in contrast a significant decrease $(\mathrm{P}<0.05)$ was observed in concentration $5 \%$ and $10 \%$ of pendimethaline and recovery with 
EDTA for 7 days. But insignificant difference in Hct value was recorded in catfishes treated with pendimethaline and recovery with EDTA for 21 day in comparison with treated groups.

Table 2: Mean values of blood indices (MCV, MCH, MCHC) and Hcton catfish (Clarias gariepinus) intoxicated with pendimethalin (stomp) and recovery with EDTA at different interval periods.

\begin{tabular}{|c|c|c|c|c|c|c|c|c|c|c|}
\hline \multirow{3}{*}{ Parameters } & \multicolumn{10}{|c|}{ Groups } \\
\hline & & & \multicolumn{4}{|c|}{7 days } & \multicolumn{4}{|c|}{21 days } \\
\hline & & Control & $\begin{array}{c}\text { Stomp } \\
5 \%\end{array}$ & $\begin{array}{l}(5 \%) \\
\text { Recovery }\end{array}$ & $\begin{array}{l}\text { Stomp } \\
10 \%\end{array}$ & $\begin{array}{c}(10 \%) \\
\text { Recovery }\end{array}$ & $\begin{array}{l}\text { Stom } \\
\text { p 5\% }\end{array}$ & $\begin{array}{l}(5 \%) \\
\text { Recovery }\end{array}$ & $\begin{array}{c}\text { Stomp } \\
10 \%\end{array}$ & $\begin{array}{c}(10 \%) \\
\text { Recovery }\end{array}$ \\
\hline \multirow[t]{2}{*}{ MCV } & $\begin{array}{c}\text { Mean } \\
\pm \\
\text { S.E }\end{array}$ & $\begin{array}{c}144.3 \\
\pm \\
5.76^{\mathrm{a}, \mathrm{b}}\end{array}$ & $\begin{array}{c}180.16 \\
\pm \\
11.13^{b}\end{array}$ & $\begin{array}{c}150.23 \\
\pm \\
2.67^{\mathrm{b}}\end{array}$ & $\begin{array}{c}180.93 \\
\pm \\
13.31^{\mathrm{a}}\end{array}$ & $\begin{array}{c}150.73 \\
\pm \\
14.3^{\mathrm{a}}\end{array}$ & $\begin{array}{c}144.59 \\
\pm \\
6.26^{\mathrm{a}, \mathrm{d}}\end{array}$ & $\begin{array}{c}136.45 \\
\pm \\
1.6^{\text {a,d }}\end{array}$ & $\begin{array}{c}134.33 \\
\pm \\
8.15^{\text {a,d }}\end{array}$ & $\begin{array}{c}119.78 \\
\pm \\
13.83^{\mathrm{c}, \mathrm{d}}\end{array}$ \\
\hline & $\%$ & 5.76 & 11.13 & 2.67 & 13.31 & 14.3 & 6.26 & 1.6 & 8.15 & 13.83 \\
\hline \multirow[t]{2}{*}{ МСН } & $\begin{array}{c}\text { Mean } \\
\pm \\
\text { S.E }\end{array}$ & $\begin{array}{c}77.79 \\
\pm \\
1.15^{\text {a,b }}\end{array}$ & $\begin{array}{c}80.57 \\
\pm \\
5.07^{\mathrm{a}}\end{array}$ & $\begin{array}{c}75.15 \\
\pm \\
2.48^{\mathrm{a}, \mathrm{b}}\end{array}$ & $\begin{array}{c}73.76 \\
\pm \\
5.86^{\text {a.b }}\end{array}$ & $\begin{array}{c}66.26 \\
\pm \\
5.55^{b}\end{array}$ & $\begin{array}{c}66.35 \\
\pm \\
2.84^{b}\end{array}$ & $\begin{array}{c}68.25 \\
\pm \\
0.6^{\mathrm{a}}\end{array}$ & $\begin{array}{l}80.72 \\
\pm \\
1.64^{a, b}\end{array}$ & $\begin{array}{c}68.3 \\
\pm \\
9.09^{\mathrm{a}, \mathrm{b}}\end{array}$ \\
\hline & $\%$ & 1.15 & 5.07 & 2.48 & 5.86 & 5.55 & 2.84 & 0.6 & 1.64 & 9.09 \\
\hline \multirow[t]{2}{*}{ МСНC } & $\begin{array}{c}\text { Mean } \\
\pm \\
\text { S.E }\end{array}$ & $\begin{array}{c}53.94 \\
\pm \\
1.5^{\mathrm{a}}\end{array}$ & $\begin{array}{c}44.77 \\
\pm \\
2.0^{b}\end{array}$ & $\begin{array}{c}49.98 \\
\pm \\
0.82^{\mathrm{c}}\end{array}$ & $\begin{array}{c}40.73 \\
\pm \\
1.02^{\mathrm{a}, \mathrm{e}}\end{array}$ & $\begin{array}{c}44.14 \\
\pm \\
1.2^{\mathrm{b}, \mathrm{c}}\end{array}$ & $\begin{array}{c}45.89 \\
\pm \\
0.45^{b}\end{array}$ & $\begin{array}{c}49.97 \\
\pm \\
0.63^{d}\end{array}$ & $\begin{array}{c}60.54 \\
\pm \\
2.56^{\text {e,f }}\end{array}$ & $\begin{array}{c}51.63 \\
\pm \\
0.37^{\mathrm{a}, \mathrm{f}}\end{array}$ \\
\hline & $\%$ & 1.5 & 2.0 & 0.82 & 1.02 & 1.2 & 0.45 & 0.63 & 2.56 & 0.37 \\
\hline \multirow[t]{2}{*}{ HCT } & $\begin{array}{c}\text { Mean } \\
\pm \\
\text { S.E }\end{array}$ & $\begin{array}{c}27.52 \\
\pm \\
1.65^{\mathrm{a}}\end{array}$ & $\begin{array}{c}34.72 \\
\pm \\
1.37^{\mathrm{b}}\end{array}$ & $\begin{array}{c}26.97 \\
\pm \\
0.96^{\mathrm{c}}\end{array}$ & $\begin{array}{c}42.42 \\
\pm \\
1.18^{\mathrm{a}}\end{array}$ & $\begin{array}{c}33.42 \\
\pm \\
1.51^{\mathrm{d}}\end{array}$ & $\begin{array}{c}27.17 \\
\pm \\
0.47^{\mathrm{a}}\end{array}$ & $\begin{array}{c}27.5 \\
\pm \\
0.67^{\mathrm{a}}\end{array}$ & $\begin{array}{c}25.75 \\
\pm \\
0.97^{\mathrm{a}}\end{array}$ & $\begin{array}{c}26.85 \\
\pm \\
1.69^{\mathrm{a}}\end{array}$ \\
\hline & $\%$ & 1.65 & 1.37 & 0.96 & 1.18 & 1.51 & 0.47 & 0.67 & 0.97 & 1.69 \\
\hline $\begin{array}{l}\text { Each valu } \\
\text { a,b,c,d.e mes } \\
\text { difference } \\
\text { values. }\end{array}$ & $\begin{array}{l}\text { esen } \\
\text { apa } \\
\text { nhic }\end{array}$ & $\begin{array}{l}\text { eans } \\
\text { betws } \\
\text { e diff }\end{array}$ & $\begin{array}{l}\text { reco } \\
\text { all gr } \\
\text { t lett }\end{array}$ & $\begin{array}{l} \pm \text { S.E. } \\
\text { s whic } \\
\text { nean th }\end{array}$ & . & n & let & . & . & $\begin{array}{l}\text { nce } \\
\text { ontrol }\end{array}$ \\
\hline
\end{tabular}

Table (3) revealed insignificant difference in lymphocyte $\%$ in catfishes treated with concentration 5\% and $10 \%$ of pendimethaline and recovery with EDTA for 7 days and 21 day in comparison with the control group. It is clear from table (3) and figure (9) that showed a significant increase $(\mathrm{P}<0.05)$ in lymphocyte \% in catfishes treated with concentration $5 \%$ of pendimethaline and recovery with EDTA for 7 days when compared with the treated group, but insignificant difference was recorded in the other groups.

Data presented in table (3) recorded insignificant difference in neutrophils $\%$ in catfishes treated with concentration $5 \%$ and $10 \%$ of pendimethaline for 7 days and 21 day when compared with the control group. Data found in table (3) and illustrated in figure (10) showed a significant decrease $(\mathrm{P}<0.05)$ in neutrophil \% in catfishes treated with concentration 5\% of pendimethaline and recovery with EDTA for 7 days and $10 \%$ for 21 day when compared with the treated groups, but insignificant difference was recorded in the other remain groups.

Statistical data of monocytes \% in table (3) a significant decrease in catfishes treated with concentration $5 \%$ and $10 \%$ of pendimethaline for 7 days and 21 day when compared with the control group, except a groups treated with pendimethalin at concentration $5 \%$ for 21 days showed insignificant decrease in monocyte percentage. Also the data showed insignificant difference in monocytes $\%$ with concentration $5 \%$ and $10 \%$ of pendimethalin and recovery with EDTA for 21 days when compared with the treated groups.

Eosinophils in table (3) observed a significant decrease $(\mathrm{P}<0.05)$ in catfishes treated with concentration $10 \%$ of pendimethaline for 7 days, while insignificant difference was recorded at concentration $5 \%$ of pendimethalin for 7 days when compared with the control group. From other hand, the data showed a significant decrease in Eosinophils $\%$ in catfishes treated with concentration $5 \%$ of pendimethaline and recovery with EDTA for 7 days when compared with the treated groups. Insignificant difference was recorded in Eosinophils percentage in group treated 
with pendimethalin at concentration $10 \%$ and recovery with EDTA for 7 day when compared with the treated groups.

Table (3):Mean values \pm S.E of Differential leukocyte count (lymphocyte, Neutrophil, Monocyte and eosinophil) on catfish( Clarias gariepinus) intoxicated with pendimethalin (stomp) and recovery with EDTA at different interval periods.

\begin{tabular}{|c|c|c|c|c|c|c|c|c|c|c|}
\hline \multirow{3}{*}{ Parameters } & \multicolumn{10}{|c|}{ Groups } \\
\hline & & Period & \multicolumn{4}{|c|}{7 days } & \multicolumn{4}{|c|}{21 days } \\
\hline & & Control & $\begin{array}{r}\text { Stomp } \\
(5 \%)\end{array}$ & $\begin{array}{c}(5 \%) \\
\text { Recovery }\end{array}$ & \begin{tabular}{|l|} 
Stomp \\
$(10 \%))$ \\
\end{tabular} & $\begin{array}{c}(10 \%) \\
\text { Recovery }\end{array}$ & $\begin{array}{l}\text { Stomp } \\
(5 \%)\end{array}$ & $\begin{array}{c}(5 \%) \\
\text { Recovery }\end{array}$ & $\begin{array}{l}\text { Stomp } \\
(10 \%)\end{array}$ & $\begin{array}{c}(10 \%) \\
\text { Recovery }\end{array}$ \\
\hline \multirow[t]{2}{*}{$\begin{array}{c}\text { Lymphocyte } \\
(\%)\end{array}$} & $\begin{array}{l}\text { Mean } \\
\pm \\
\text { S.E }\end{array}$ & $\begin{array}{l}85.65 \pm \\
0.80^{\mathrm{a}}\end{array}$ & $\begin{array}{l}87.75 \\
\pm \\
0.56^{\mathrm{a}, \mathrm{b}}\end{array}$ & $\begin{array}{l}89.0 \\
\pm \\
0.91^{c, d}\end{array}$ & \begin{tabular}{|l}
93.07 \\
\pm \\
$0.96^{\mathrm{a}, \mathrm{b}}$
\end{tabular} & $\begin{array}{l}89.50 \\
\pm \\
1.04^{b, d}\end{array}$ & $\begin{array}{l}87.75 \\
\pm \\
1.37^{\mathrm{a}, \mathrm{b}}\end{array}$ & $\begin{array}{l}87.75 \\
\pm \\
\mathbf{0 . 8 5} \\
\end{array}$ & $\begin{array}{l}89.25 \\
\pm \\
1.49^{a, b}\end{array}$ & $\begin{array}{l}90.25 \\
\pm \\
2.65^{b, d}\end{array}$ \\
\hline & $\%$ & & & & & & & & & \\
\hline \multirow[t]{2}{*}{$\begin{array}{c}\text { Neutrophil } \\
(\%)\end{array}$} & $\begin{array}{l}\text { Mean } \\
\pm \\
\text { S.E }\end{array}$ & $\begin{array}{l}7.25 \\
\pm \\
1.65^{\mathrm{a}, \mathrm{b}} \\
\end{array}$ & $\begin{array}{l}8.25 \\
\pm \\
0.47^{\mathrm{a}, \mathrm{c}}\end{array}$ & $\begin{array}{l}8.00 \\
\pm \\
0.91^{b}\end{array}$ & \begin{tabular}{|l|}
5.00 \\
\pm \\
$0.40^{\mathrm{a}, \mathrm{b}}$
\end{tabular} & $\begin{array}{l}6.75 \\
\pm \\
0.85^{\text {a,b }}\end{array}$ & $\begin{array}{l}7.75 \\
\pm \\
0.47^{\mathrm{a}, \mathrm{b}}\end{array}$ & $\begin{array}{l}8.50 \\
\pm \\
0.64^{a, b}\end{array}$ & $\begin{array}{l}7.75 \\
\pm \\
0.75^{\mathrm{a}}\end{array}$ & $\begin{array}{l}5.25 \\
\pm \\
2.01^{b, c}\end{array}$ \\
\hline & $\%$ & & & & & & & & & \\
\hline \multirow[t]{2}{*}{$\begin{array}{l}\text { Monocyte } \\
(\%)\end{array}$} & $\begin{array}{l}\text { Mean } \\
\pm \\
\text { S.E }\end{array}$ & $\begin{array}{l}6.25 \\
\pm \\
1.10^{\mathrm{a}}\end{array}$ & $\begin{array}{l}\mathbf{3 . 0 0} \\
\pm \\
\mathbf{0 . 7 0}\end{array}$ & $\begin{array}{l}2.25 \\
\pm \\
0.50^{b}\end{array}$ & $\begin{array}{l}2.50 \\
\pm \\
0.28^{b}\end{array}$ & $\begin{array}{l}3.50 \\
\pm \\
0.28^{b, c}\end{array}$ & $\begin{array}{l}4.75 \\
\pm \\
0.75^{\mathrm{a}, \mathrm{c}}\end{array}$ & $\begin{array}{l}3.75 \\
\pm \\
\mathbf{0 . 8 5}\end{array}$ & $\begin{array}{l}3.50 \\
\pm \\
0.64^{b, c}\end{array}$ & $\begin{array}{l}3.75 \\
\pm \\
\mathbf{0 . 8 5}\end{array}$ \\
\hline & $\%$ & & & & & & & & & \\
\hline \multirow[t]{2}{*}{$\begin{array}{c}\text { Eosinophil } \\
(\%)\end{array}$} & $\begin{array}{l}\text { Mean } \\
\pm \\
\text { S.E }\end{array}$ & $\begin{array}{l}1.25 \\
\pm \\
0.41 \mathrm{a} \\
\end{array}$ & $\begin{array}{l}1.25 \\
\pm \\
0.24 a \\
\end{array}$ & \begin{tabular}{|l}
0.25 \\
\pm \\
$0.25 b$ \\
\end{tabular} & \begin{tabular}{|l|}
0.25 \\
\pm \\
$0.25 b$ \\
\end{tabular} & $\begin{array}{l}0.25 \\
\pm \\
0.25 b \\
\end{array}$ & $\begin{array}{l}0.00 \\
\pm \\
0.0 b\end{array}$ & $\begin{array}{l}0.00 \\
\pm \\
0.0 b \\
\end{array}$ & $\begin{array}{l}0.00 \\
\pm \\
0.0 b\end{array}$ & $\begin{array}{l}0.00 \\
\pm \\
0.0 b\end{array}$ \\
\hline & $\%$ & & & & & & & & & \\
\hline $\begin{array}{l}\text { Each value } 1 \\
\text { a,b,c,d.e } \text { mean } \\
\text { difference a } \\
\text { values. }\end{array}$ & th & diff & 1 & S.E. & 8 . & 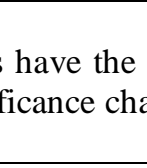 & 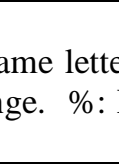 & 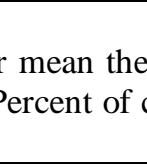 & 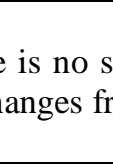 & $\begin{array}{l}\text { nificance } \\
\text { n contro }\end{array}$ \\
\hline
\end{tabular}

\section{Biochemical parameters:}

Data found in table (4) showed a significant increase $(\mathrm{P}<0.05)$ in serum ALAT and ASAT enzymes activities in catfishes treated with 5\% and 10\% of pendimethalin for 7 and 21 day when compared with the control group. On the other hand cat fishes treated with pendimethalin at concentration 5\% and 10\% and recovery with EDTA showed a significant decrease $(\mathrm{P}<0.05)$ in serum ALAT and ASAT enzymes activities for 7 and 21 day when compared with treated groups, except group treated with Pendimethalin and recovery with EDTA at concentration $10 \%$ after 21 day showed a significant increase $(\mathrm{P}<0.05)$ in serum ALAT only Where the Mean and S.E was $(50.0 \pm 5.4),(81 \pm 6.1)$ in control group and was(166.0 \pm 5.7$),(209.0 \pm 9.3)$ in catfishes treated with concentration $10 \%$ of Pendimethalin for 7days for ALAT and ASAT respectively.

Serum alkaline phosphatase enzyme activity illustrated in table $(4)$ demonstrated a significant increase $(\mathrm{P}<0.05)$ in cat fishes treated with pendimethaline at concentration 5\% and $10 \%$ for 7 and 21 day in comparison with the control group, except cat fishes treated with pendimethaline at concentration 5\% for 21 day observed insignificant increase in serum ALP in comparison with the control group. Insignificant difference was recorded in serum ALP enzyme activity in groups treated with pendimethaline and recovery with EDTA at concentration 5\% and 10\% for 7 and 21 day when compared with treated groups.

Statistical data in table (4) observed insignificant increase in serum (GGT) activity in group treated with pendimethaline for 7 day at concentration $5 \%$ when compared with the control group. On contrast a significant increase $(\mathrm{P}<0.05)$ in serum GGT was recorded in group treated with pendimethaline at concentration $10 \%$ for 7 day. 
Also a significant increase $(\mathrm{P}<0.05)$ was showed in serum GGT activity in cat fishes treated with pendimethaline at concentration $5 \%$ and $10 \%$ for 21 day in comparison with the control. Catfishes groups treated with pendimethaline at concentration 5\% and 10\% and recovery with EDTA for 7 and 21 day recorded insignificant decrease in serum GGT activity, except group treated with pendimethaline at concentration 10\% and recovery with EDTA for 7 day showed a significant decrease $(\mathrm{P}<0.05)$ when compared with treated groups.

Table (4): Mean values \pm S.E of liver functions tests on catfish (Clarias gariepinus) intoxicated with pendimethalin (stomp) and recovery with EDTA at different interval periods.

\begin{tabular}{|c|c|c|c|c|c|c|c|c|c|c|}
\hline \multirow[t]{3}{*}{ Parameters } & \multicolumn{10}{|c|}{ Groups } \\
\hline & & \multirow{2}{*}{\begin{tabular}{|r|} 
Period \\
Control \\
\end{tabular}} & \multicolumn{4}{|c|}{7 days } & \multicolumn{4}{|c|}{21 days } \\
\hline & & & $\begin{array}{l}\text { Stomp } \\
5 \%\end{array}$ & $\begin{array}{c}(5 \%) \\
\text { Recovery }\end{array}$ & $\begin{array}{l}\text { Stomp } \\
10 \%\end{array}$ & $\begin{array}{c}(10 \%) \\
\text { Recovery }\end{array}$ & $\begin{array}{l}\text { Stomp } \\
5 \%\end{array}$ & $\begin{array}{c}(5 \%) \\
\text { Recovery }\end{array}$ & $\begin{array}{l}\text { Stomp } \\
10 \%\end{array}$ & $\begin{array}{c}(10 \%) \\
\text { Recovery }\end{array}$ \\
\hline \multirow{3}{*}{$\begin{array}{c}\text { ALAT } \\
(\mathbf{U} / \mathbf{L})\end{array}$} & Mean & $50.0 \pm$ & 123 & 50.2 & 166 & 114.5 & 151.7 & 87.7 & 72.5 & 87.7 \\
\hline & $\begin{array}{c} \pm \\
\text { S.E }\end{array}$ & $5.4^{\mathrm{a}}$ & $\stackrel{ \pm}{ \pm}$ & $\begin{array}{c} \pm \\
4.7^{\mathrm{a}}\end{array}$ & $\begin{array}{c} \pm \\
5.7^{\mathfrak{c}}\end{array}$ & $\begin{array}{c} \pm \\
7.4^{b}\end{array}$ & $\begin{array}{c} \pm \\
4.1^{\mathrm{c}}\end{array}$ & $3.7^{\mathrm{d}}$ & $\begin{array}{c} \pm \\
3.7^{\mathrm{c}}\end{array}$ & $7^{ \pm}$ \\
\hline & $\%$ & -- & 146 & 0.4 & 233 & 129 & 203.4 & 75.4 & 45 & 75.4 \\
\hline \multirow{3}{*}{$\begin{array}{l}\text { ASAT } \\
\text { (U/L) }\end{array}$} & Mean & 81 & 176.2 & 100.5 & 209 & 152.7 & 172.5 & 120.2 & 208 & 158 \\
\hline & $\begin{array}{c} \pm \\
\text { S.E }\end{array}$ & $\begin{array}{c} \pm \\
6.1^{\mathrm{a}}\end{array}$ & $\stackrel{ \pm}{ \pm}{ }_{10.9^{b}}$ & $\stackrel{ \pm}{12.1^{\mathrm{a}}}$ & $\begin{array}{c} \pm \\
9.3^{\mathrm{c}}\end{array}$ & $11 \stackrel{ \pm}{d}^{\mathrm{d}, \mathrm{b}}$ & $\begin{array}{c} \pm \\
7.2^{b}\end{array}$ & $5.4^{\mathrm{e}, \mathrm{a}}$ & $\stackrel{ \pm}{11.9^{\mathrm{c}}}$ & $\stackrel{ \pm}{ \pm}^{7.9^{b}}$ \\
\hline & $\%$ & -- & 117.5 & 24.0 & 158.8 & 88.5 & 112.9 & 48.3 & 157.4 & 95.0 \\
\hline \multirow{3}{*}{$\begin{array}{c}\mathbf{A L P} \\
\text { (U/L) }\end{array}$} & Mean & 49.7 & 79.5 & 69.2 & 82.2 & 83.5 & 57.2 & 58.0 & 71.2 & 63.5 \\
\hline & $\begin{array}{c} \pm \\
\text { S.E }\end{array}$ & $\begin{array}{c} \pm \\
4.5^{\mathrm{a}}\end{array}$ & $4 .^{\mathbf{b}, \mathrm{c}}$ & $\stackrel{ \pm}{\mathbf{t . 3}^{\mathbf{b}, \mathbf{c}}}$ & 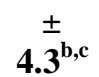 & $\begin{array}{c} \pm \\
4.8^{c}\end{array}$ & $\stackrel{ \pm}{{ }^{ \pm} .^{\text {a,d }}}$ & $\stackrel{ \pm}{ \pm .0^{\mathrm{a}, \mathrm{d}, \mathrm{e}}}$ & 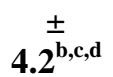 & $\stackrel{{ }^{ \pm} .^{\mathrm{d}, \mathrm{e}}}{ }$ \\
\hline & $\%$ & -- & \begin{tabular}{|l|l|}
59.9 \\
\end{tabular} & 39.2 & $\begin{array}{l}65.3 \\
\end{array}$ & 68.0 & 15.0 & 16.7 & 43.2 & 27.7 \\
\hline \multirow{4}{*}{$\begin{array}{l}\text { GGT } \\
\text { (U/L) }\end{array}$} & Mean & 5.0 & 9.5 & 7.7 & 14.2 & 6.5 & 13.5 & 11 & 15.5 & 11.2 \\
\hline & \pm & \pm & \pm & \pm & \pm & + & \pm & + & \pm & \pm \\
\hline & S.E & $1.0^{\mathrm{a}}$ & $1.0^{\mathrm{a}, \mathrm{b}}$ & $0.8^{\mathrm{a}, \mathrm{d}}$ & $2.8^{\mathrm{b}, \mathrm{c}}$ & $1.3^{\mathrm{a}, \mathrm{d}}$ & $1.7^{\mathbf{b , c}}$ & $0.9^{\mathbf{b}, \mathbf{d}, \mathbf{c}}$ & $2.5^{\mathrm{c}, \mathrm{e}}$ & $0.7^{b, d, c}$ \\
\hline & $\%$ & -- & 90 & 54 & 184 & 30 & 170 & 120 & 210 & 124 \\
\hline
\end{tabular}

Table (5) showed a significant increase $(\mathrm{P}<0.05)$ in serum total protein in catfishes treated with concentration 5\% and $10 \%$ pendimethaline for 7 and 21 days when compared with the control group. Also, there are a significant increase $(\mathrm{P}<0.05)$ was recorded in total Protein level in catfishes treated with concentration $5 \%$ of pendimethaline and recovery with EDTA for 7 days when compared with the treated group, also the data found that, there are a significant increase $(\mathrm{P}<0.05)$ in serum total protein level in catfishes treated with concentration10\% of pendimethaline and recovery with EDTA for 21 days when compared with the treated group, While insignificant difference in the other groups.

Serum albumin level recorded in table $(5)$ demonstrated a significant increase $(\mathrm{P}<0.05)$ in catfishes treated with pendimethaline at concentration $5 \%$ and $10 \%$ for 21 days when compared with the control group, while insignificant difference was recorded in serum albumin level in catfishes treated with concentration $5 \%$ and $10 \%$ of pendimethaline for 7 day days when compared with the control group.

The resulted data, found in table $(5)$ increase $(\mathrm{P}<0.05)$ in serum globulin level in catfishes treated with pendimethaline at concentration 5\% and 10\% for 7 days and 21 days when compared with the control group, except a group treated with Pendimethaline at concentration $5 \%$ for 21 days recorded insignificant increase when compared with the control group.

From the other hand, there are a significant increase $(\mathrm{P}<0.05)$ in globulin level in catfishes treated with pendimethaline at concentration 5\% and recovery with EDTA for 7 days when compared with the treated group, also there are a significant increase $(\mathrm{P}<0.05)$ in globulin level in catfishes treated with Pendimethaline at concentration $10 \%$ and recovery with EDTA for 21 days when compared with the treated group, but insignificant differences was recorded in the other treated groups. 
Table (5): Mean values \pm S.E of Total protein, albumin, and globulin on catfish (Clarias gariepinus) intoxicated with pendimethalin (stomp) and recovery with EDTA at different interval periods.

\begin{tabular}{|c|c|c|c|c|c|c|c|c|c|c|}
\hline \multirow[t]{3}{*}{ Parameters } & \multicolumn{10}{|c|}{ Groups } \\
\hline & \multirow[t]{2}{*}{---} & Period & \multicolumn{4}{|c|}{7 days } & \multicolumn{4}{|c|}{21 days } \\
\hline & & Control & $\begin{array}{c}\text { Stomp } \\
(5 \%)\end{array}$ & $\begin{array}{c}(5 \%) \\
\text { Recovery }\end{array}$ & $\begin{array}{l}\text { Stomp } \\
(10 \%)\end{array}$ & $\begin{array}{c}(10 \%) \\
\text { Recovery }\end{array}$ & $\begin{array}{c}\text { Stomp } \\
(5 \%)\end{array}$ & $\begin{array}{c}(5 \%) \\
\text { Recovery }\end{array}$ & $\begin{array}{l}\text { Stomp } \\
(10 \%)\end{array}$ & $\begin{array}{c}(10 \%) \\
\text { Recovery }\end{array}$ \\
\hline \multirow{3}{*}{$\begin{array}{c}\text { T. Protein } \\
\text { (g/dl) }\end{array}$} & Mean & 5.7 & 6.9 & $7.2 \pm$ & 8.1 & 7.4 & 6.7 & 6.9 & 7.2 & 8.1 \\
\hline & $\begin{array}{c} \pm \\
\text { S.E }\end{array}$ & $\begin{array}{c} \pm \\
0.19^{\mathrm{a}}\end{array}$ & $\stackrel{ \pm}{\mathbf{0}} 2^{\mathrm{b}}$ & $0.43^{c}$ & $\stackrel{ \pm}{\mathbf{0 . 3 0}}$ & $\begin{array}{c} \pm \\
0.19^{\mathrm{b}, c}\end{array}$ & $\begin{array}{c} \pm \\
0.15^{b}\end{array}$ & $\begin{array}{c} \pm \\
0.10^{b}\end{array}$ & $\begin{array}{l} \pm \\
0.29^{b}\end{array}$ & $\begin{array}{c} \pm \\
0.73^{c}\end{array}$ \\
\hline & $\%$ & --- & 21.05 & 26.3 & 42.1 & 29.8 & 17.5 & 21.05 & 26.3 & 42.10 \\
\hline \multirow[t]{2}{*}{$\begin{array}{l}\text { Albumin } \\
\text { (g/dl) }\end{array}$} & $\begin{array}{c}\text { Mean } \\
\pm \\
\text { S.E }\end{array}$ & $\begin{array}{c}2.10 \\
\pm \\
0.02^{\mathrm{a}}\end{array}$ & $\begin{array}{c}2.22 \\
\pm \\
0.1^{\mathrm{a}}\end{array}$ & $\begin{array}{c}2.04 \\
\pm \\
0.04^{\mathrm{a}, \mathrm{c}}\end{array}$ & $\begin{array}{c}2.08 \\
\pm \\
0^{\mathrm{a}, \mathrm{co}}\end{array}$ & $\begin{array}{c}2.07 \\
\pm \\
0.02^{\mathrm{a}, \mathrm{c}}\end{array}$ & $\begin{array}{c}2.71 \\
\pm \\
0^{b}\end{array}$ & $\begin{array}{c}1.97 \\
\pm \\
0.09^{b}\end{array}$ & $\begin{array}{c}2.82 \\
\pm \\
0.03^{c}\end{array}$ & $\begin{array}{c}2.10 \\
\pm \\
0.03^{\mathrm{a}, \mathrm{c}}\end{array}$ \\
\hline & $\%$ & $-\cdots$ & 5.71 & -2.85 & -0.59 & -1.42 & 29.04 & -6.19 & 34.2 & $\mathbf{0}$ \\
\hline \multirow[t]{2}{*}{$\begin{array}{l}\text { Globulin } \\
\text { (g/dl) }\end{array}$} & $\begin{array}{c}\text { Mean } \\
\pm \\
\text { S.E }\end{array}$ & $\begin{array}{c}3.62 \\
\pm \\
0.20^{\mathrm{a}}\end{array}$ & $\begin{array}{c}4 . \\
7 \pm \\
0.28 \\
\text { d }\end{array}$ & $\begin{array}{c}5.17 \\
\pm \\
0.46^{c}\end{array}$ & $\begin{array}{c}6.07 \\
\pm \\
0.25^{\text {b,e }}\end{array}$ & $\begin{array}{c}5.42 \\
\pm \\
0.18^{b, e}\end{array}$ & $\begin{array}{c}4.02 \\
\pm \\
0.22^{\mathrm{a}} \\
\mathrm{d}\end{array}$ & $\begin{array}{c}4.98 \\
\pm \\
0.15^{\text {d,e }}\end{array}$ & $\begin{array}{c}4.44 \\
\pm \\
0.26^{b, e}\end{array}$ & $\begin{array}{c}6.01 \\
\pm \\
0.38^{c}\end{array}$ \\
\hline & $\%$ & -- & 29.8 & 42.8 & 67.6 & 49.7 & 11.04 & 37.5 & 22.6 & 66.02 \\
\hline \multicolumn{11}{|c|}{$\begin{array}{l}\text { Each value represented means of } 5 \text { records } \pm \text { S.E. } \\
\text { a,b,c,d.e means comparison between all groups which the groups have the same letter mean there is no significance } \\
\text { difference and which have different letter mean there is a significance change. \%: Percent of changes from control } \\
\text { values. }\end{array}$} \\
\hline
\end{tabular}

Data found in table $(6)$ showed a significant increase $(\mathrm{P}<0.05)$ in CPK enzyme activity in catfishes treated with concentration $5 \%$ and $10 \%$ of pendimethaline for 7 and 21 day when compared with the control group. From the other hand catfishes treated with pendimethaline at concentration $10 \%$ and recovery with EDTA recorded a significant decrease $(\mathrm{P}<0.05)$ in $\mathrm{CPK}$ enzyme activity for 7 and 10 days when compared with treated groups, While insignificant decrease in CPK enzyme activity was observed in groups treated with pendimethaline at concentration $5 \%$ and recovery with EDTA for 7 and 21 days when compared with the treated groups.

LDH enzyme activity in table (6)demonstrated a significant increase $(\mathrm{P}<0.05)$ in catfishes treated with concentration $5 \%$ and $10 \%$ of pendimethaline for 7 and 21 day when compared with the control group. In contrast a highly significant decrease $(\mathrm{P}<0.05)$ in LDH enzyme activity was showed in catfishes treated with pendimethaline and recovery with EDTA at concentration $5 \%$ and $10 \%$ for 7 days and 21 day when compared with the treated groups, except in group treated with pendimethaline at concentration $5 \%$ for 21 day which revealed that insignificant decrease in serum LDH enzyme activity when compared with the treated groups.

Plasma glucose level in table $(6)$ revealed a significant increase $(\mathrm{P}<0.05)$ in catfishes treated with pendimethaline at concentration $5 \%$ and $10 \%$ for 7 days and 21 day when compared with the control group. Statistical data in table (5) and figure () observed that catfishes treated with pendimethaline and recovery with EDTA at concentration 10\% for 7 and 21day showed a significant decrease $(\mathrm{P}<0.05)$ in plasma glucose level when compared with the treated groups, while insignificant decrease in Plasma glucose level was recoded in groups treated withPendimethaline and recovery with EDTA at concentration 5\% for 7 and 21 day in comparison with the control group. 
Table (6): Mean values \pm S.Eof heart functions tests \& Glucose on catfish (Clarias gariepinus) intoxicated with pendimethalin (stomp) and recovery with EDTA at different interval periods.

\begin{tabular}{|c|c|c|c|c|c|c|c|c|c|c|}
\hline \multirow[t]{3}{*}{ Parameters } & \multicolumn{10}{|c|}{ Groups } \\
\hline & & Period & \multicolumn{4}{|c|}{7 days } & \multicolumn{4}{|c|}{21 days } \\
\hline & & Control & $\begin{array}{c}\text { Stomp } \\
5 \%\end{array}$ & $\begin{array}{c}(5 \%) \\
\text { Recovery }\end{array}$ & $\begin{array}{c}\text { Stomp } \\
10 \% \\
\end{array}$ & $\begin{array}{c}(10 \%) \\
\text { Recovery }\end{array}$ & $\begin{array}{c}\text { Stomp } \\
5 \%\end{array}$ & $\begin{array}{c}(5 \%) \\
\text { Recovery } \\
\end{array}$ & $\begin{array}{c}\text { Stomp } \\
10 \% \\
\end{array}$ & $\begin{array}{c}(10 \%) \\
\text { Recovery }\end{array}$ \\
\hline \multirow{3}{*}{$\begin{array}{l}\text { CPK } \\
(\mathbf{U} / \mathbf{L})\end{array}$} & Mean & 780.5 & 1195.2 & 1092.2 & 3159.2 & 1372.7 & 1073.7 & 997.7 & 1488.5 & 1131.6 \\
\hline & $\begin{array}{c} \pm \\
\text { S.E }\end{array}$ & $\begin{array}{c} \pm \\
63.4^{\mathrm{a}}\end{array}$ & $\begin{array}{c} \pm \\
36.2^{\mathrm{b}, \mathrm{e}}\end{array}$ & $\begin{array}{c} \pm \\
42.3^{b}\end{array}$ & $\begin{array}{c} \pm \\
161.6^{c}\end{array}$ & $\begin{array}{c} \pm \\
134.8^{\mathrm{e}, \mathrm{d}}\end{array}$ & $\begin{array}{c} \pm \\
28.4^{b}\end{array}$ & $\begin{array}{c} \pm \\
39.7^{\mathrm{a}, \mathrm{b}}\end{array}$ & $\stackrel{ \pm}{42.5^{d}}$ & $\begin{array}{c} \pm \\
38.2^{b}\end{array}$ \\
\hline & $\%$ & ----- & 53.13 & 39.93 & 304.76 & 75.87 & 37.56 & 27.82 & 90.71 & 44.98 \\
\hline \multirow[t]{2}{*}{$\begin{array}{l}\mathbf{L D H} \\
(\mathbf{U} / \mathbf{L})\end{array}$} & $\begin{array}{c}\text { Mean } \\
\pm \\
\text { S.E }\end{array}$ & $\begin{array}{c}648 \\
\pm \\
20.5^{\mathrm{a}}\end{array}$ & $\begin{array}{c}1726.7 \\
\pm \\
212.2^{b}\end{array}$ & $\begin{array}{c}878.7 \\
\pm \\
71.2^{\mathrm{a}, \mathrm{d}}\end{array}$ & $\begin{array}{c}2391.7 \\
\pm \\
443.4^{c}\end{array}$ & $\begin{array}{c}1279.7 \\
\pm \\
121.9^{b, d}\end{array}$ & $\begin{array}{c}1399.7 \\
\pm \\
90.0^{b, d}\end{array}$ & $\begin{array}{c}1117.5 \\
\pm \\
37.0^{\mathrm{a}, \mathrm{d}}\end{array}$ & $\begin{array}{c}1982 \\
2 \pm \\
45.7^{\mathrm{c}, \mathrm{e}}\end{array}$ & $\begin{array}{c}1227.2 \\
\pm \\
19.3^{b, d}\end{array}$ \\
\hline & $\%$ & ----- & 166.46 & 36.60 & 269.08 & 97.48 & 116.00 & 72.45 & 205.89 & 89.38 \\
\hline \multirow[t]{2}{*}{$\begin{array}{l}\text { Glucose } \\
\text { (mg/dl) }\end{array}$} & $\begin{array}{c}\text { Mean } \\
\pm \\
\text { S.E }\end{array}$ & $\begin{array}{c}50.2 \\
\pm \\
4.6^{a}\end{array}$ & $\begin{array}{c}73.7 \\
\pm \\
12.0^{b, d}\end{array}$ & $\begin{array}{c}58.2 \\
\pm \\
4.7^{\mathrm{a}, \mathrm{b}}\end{array}$ & $\begin{array}{c}124.2 \\
\pm \\
9.8^{c}\end{array}$ & $\begin{array}{c}87.2 \\
\pm \\
10.9^{d}\end{array}$ & $\begin{array}{c}84.7 \\
\pm \\
3.0^{d}\end{array}$ & $\begin{array}{c}68.2 \\
\pm \\
7.1^{\mathrm{a}, \mathrm{b}, \mathrm{d}}\end{array}$ & $\begin{array}{r}114.0 \\
7.0^{c}\end{array}$ & $\begin{array}{c}90.7 \\
\pm \\
4.8^{d}\end{array}$ \\
\hline & $\%$ & ----- & 46.81 & 15.93 & 147.41 & 73.70 & 68.72 & 35.85 & 127.09 & 80.67 \\
\hline
\end{tabular}

\section{Antioxidant and oxidative stress in liver tissue:-}

Catalase enzyme activity of the catfishes showed a significant decrease $(\mathrm{P}<0.05)$ in groups treated with concentration 5\% and 10\% pendimethaline for 7 and 21 days when compared with the control group as in table (7) On the other hand, there are a significant increase $(\mathrm{P}<0.05)$ was recorded in catalase enzyme activity in catfishes treated with concentration $5 \%$ and $10 \%$ of pendimethaline and recovery with EDTA for 7 and 21 days when compared with the treated groups, except group treated with concentration 5\% of pendimethaline and recovery with EDTA for 7 days observed insignificant increase $(\mathrm{P}<0.05)$ in catalase enzyme activity in liver tissue when compared with the treated groups.

Reduced glutathione level recorded ( GSH ) in table (7) demonstrated a significant decrease ( $\mathrm{P}<0.05)$ in GSH in liver tissue of catfishes treated with pendimethaline at concentration 5\% and $10 \%$ for 7 days and 21 day except catfishes treated with pendimethaline at concentration 5\% for 7 days showed insignificant differences in GSH level . Insignificant differences in GSH level was observed in catfishes treated with pendimethaline at concentration 5\% and $10 \%$ for 7 days and 21 day and recovery with EDTA for 7 and 21 day when compared with the treated groups except, catfishes treated with pendimethalin at concentration $10 \%$ for 21 day revealed a significant increase $(\mathrm{P}<0.05)$ in GSH level in liver tissue in comparison with the treated groups.

The resulted data, found in table (7) a significant decrease $(\mathrm{P}<0.05)$ in liver glutathione reductase $(\mathrm{GR})$ level in catfishes treated with pendimethaline at concentration 5\% and $10 \%$ for 7 days and 21 days when compared with the control group. From the other hand, catfishes treated with pendimethaline at concentration 5\% and $10 \%$ and recovery with EDTA for 7 days and 21 days revealed a significant increase $(\mathrm{P}<0.05)$ in liver $(\mathrm{GR})$ level in comparison with the treated groups.

MDA of the liver catfish showed a significant increase $(\mathrm{P}<0.05)$ in catfishes treated with concentration $5 \%$ and 10 $\%$ pendimethaline for 7 and 21 days when compared with the control group as in table (8) on the other hand, there are a significant decrease $(\mathrm{P}<0.05)$ in $(\mathrm{MDA})$ level was revealed in catfishes treated with pendimethaline at concentration 5\% and $10 \%$ and recovery with EDTA for 7days and 21 day when compared with the treated groups. Except group treated with pendimethalin at concentration $10 \%$ and recovery with EDTA for 21 days recorded insignificant decrease $(\mathrm{P}<0.05)$ in $(\mathrm{MDA})$ level when compared with the treated groups.

Data found in table (8) observed that a significant decrease $(\mathrm{P}<0.05)$ in SOD enzyme activity in the liver tissue of catfishes treated with concentration 5\% and $10 \%$ pendimethaline for 7 and 21 days when compared with the control 
group, while catfishes treated with concentration 5\% and 10\% pendimethaline and recovery with EDTA for 7 and 21 days revealed insignificant increase in liver SOD enzyme activity when compared with treated groups.

Table (7): Mean values \pm S.E of antioxidant markers in liver tissue of catfish (Clarias gariepinus intoxicated

\begin{tabular}{|c|c|c|c|c|c|c|c|c|c|c|}
\hline \multirow[t]{3}{*}{ Parameters } & \multicolumn{10}{|c|}{ Groups } \\
\hline & \multirow[t]{2}{*}{---- } & Period & \multicolumn{4}{|c|}{7 days } & \multicolumn{4}{|c|}{21 days } \\
\hline & & Control & $\begin{array}{c}\text { Stomp } \\
5 \%\end{array}$ & $\begin{array}{c}(5 \%) \\
\text { Recovery }\end{array}$ & $\begin{array}{l}\text { Stomp } \\
10 \%\end{array}$ & $\begin{array}{c}(10 \%) \\
\text { Recovery }\end{array}$ & $\begin{array}{c}\text { Stomp } \\
5 \%\end{array}$ & $\begin{array}{c}(5 \%) \\
\text { Recovery }\end{array}$ & $\begin{array}{c}\text { Stomp } \\
10 \%\end{array}$ & $\begin{array}{c}(10 \%) \\
\text { Recovery }\end{array}$ \\
\hline \multirow[t]{2}{*}{$\begin{array}{c}\text { Catalase } \\
\text { (U/g tissue) }\end{array}$} & $\begin{array}{l}\text { Mean士 } \\
\text { S.E }\end{array}$ & $\begin{array}{l}13.77 \\
\pm \\
0.53^{\mathrm{a}}\end{array}$ & $\begin{array}{l}11.1 \\
\pm \\
1.1^{b, d}\end{array}$ & $\begin{array}{l}12.6 \\
\pm \\
0.2^{a, b}\end{array}$ & $\begin{array}{l}7.4 \\
\pm \\
1.13^{c}\end{array}$ & $\begin{array}{l}12.07 \\
\pm \\
\mathbf{0 . 8 3}^{\mathbf{a}, \mathrm{b}}\end{array}$ & $\begin{array}{l}9.5 \\
\pm \\
0.27^{d}\end{array}$ & $\begin{array}{l}11.9 \\
\pm \\
0.18^{a, b}\end{array}$ & $\begin{array}{l}9.8 \\
\pm \\
0.38^{d}\end{array}$ & $\begin{array}{l}12.4 \\
\pm \\
0.29^{\mathrm{a}, \mathrm{b}}\end{array}$ \\
\hline & $\%$ & ----- & -18.9 & -8.02 & -45.9 & -11.8 & -30.6 & -13.1 & -28.4 & -9.4 \\
\hline \multirow{2}{*}{$\begin{array}{c}\text { Reduced } \\
\text { glutathione } \\
\text { (GSH) } \\
\text { (U/g tissue) }\end{array}$} & $\begin{array}{l}\text { Mean士 } \\
\text { S.E }\end{array}$ & $\begin{array}{l}14.7 \\
\pm \\
0.33^{\mathrm{a}, \mathrm{c}} \\
\end{array}$ & $\begin{array}{l}13.8 \\
\pm \\
0.35^{\text {b,c }} \\
\end{array}$ & $\begin{array}{l}14.6 \\
\pm \\
0.34^{c}\end{array}$ & $\begin{array}{l}13.07 \\
\pm \\
\mathbf{0 . 3 3}^{\mathrm{b}} \\
\end{array}$ & $\begin{array}{l}13.6 \\
\pm \\
0.18^{\text {b,e }} \\
\end{array}$ & $\begin{array}{l}13.7 \\
\pm \\
0.31^{b, e}\end{array}$ & $\begin{array}{l}14.2 \\
\pm \\
0.35^{c, e} \\
\end{array}$ & $\begin{array}{l}9.9 \\
\pm \\
0.23^{d}\end{array}$ & $\begin{array}{l}10.9 \\
\pm \\
0.24^{\text {f }}\end{array}$ \\
\hline & $\%$ & ----- & -0.61 & -0.68 & -11.08 & 9.1 & -7.4 & -3.4 & -32.6 & -25.8 \\
\hline \multirow{2}{*}{$\begin{array}{c}\text { Glutathione } \\
\text { reductase } \\
(\mathbf{G R}) \\
\text { ( U/g tissue ) }\end{array}$} & $\begin{array}{l}\text { Mean } \pm \\
\text { S.E }\end{array}$ & $\begin{array}{l}4292 \\
\pm \\
115.9^{a}\end{array}$ & $\begin{array}{l}4117.5 \pm \\
65.2^{b}\end{array}$ & $\begin{array}{l}4160.3 \\
\pm \\
30.9^{a}\end{array}$ & $\begin{array}{l}4107.5 \\
\pm \\
6.5^{b}\end{array}$ & $\begin{array}{l}4135.3 \\
\pm \\
21.2^{a}\end{array}$ & $\begin{array}{l}4041.2 \\
\pm \\
47.7^{b}\end{array}$ & $\begin{array}{l}4142.7 \\
\pm \\
21.7^{c}\end{array}$ & $\begin{array}{l}4001.5 \\
\pm \\
38.1^{b}\end{array}$ & $\begin{array}{l}4116.5 \\
\pm \\
7.3^{c}\end{array}$ \\
\hline & $\%$ & & -104.0 & -3.06 & -4.2 & -5.8 & -5.8 & -3.4 & -6.7 & -4.08 \\
\hline
\end{tabular}

Each value represented means of 5 records \pm S.E.

a,b,c,d.e means comparison between all groups which the groups have the same letter mean there is no significance difference and which have different letter mean there is a significance change. \%: Percent of changes from control values.

with pendimethalin (stomp) and recovery with EDTA at different interval periods.

Table( 8):- Mean values \pm S.E of antioxidant markers in liver tissue and oxidative stressof catfish (Clarias gariepinus intoxicated with pendimethalin (stomp) and recovery with EDTA at different interval periods.

\begin{tabular}{|c|c|c|c|c|c|c|c|c|c|c|}
\hline \multirow[t]{3}{*}{ Parameters } & \multicolumn{10}{|c|}{ Groups } \\
\hline & \multirow[t]{2}{*}{--.---- } & Period & \multicolumn{4}{|c|}{7 days } & \multicolumn{4}{|c|}{21 days } \\
\hline & & Control & $\begin{array}{c}\text { Stomp } \\
(5 \%)\end{array}$ & $\begin{array}{c}(5 \%) \\
\text { Recovery }\end{array}$ & $\begin{array}{l}\text { Stomp } \\
(10 \%)\end{array}$ & $\begin{array}{c}(10 \%) \\
\text { Recovery }\end{array}$ & $\begin{array}{c}\text { Stomp } \\
(5 \%)\end{array}$ & $\begin{array}{c}(5 \%) \\
\text { Recovery }\end{array}$ & $\begin{array}{l}\text { Stomp } \\
(10 \%)\end{array}$ & $\begin{array}{c}(10 \%) \\
\text { Recovery }\end{array}$ \\
\hline \multirow{3}{*}{$\underset{(\mathrm{U} / \mathrm{g} \text { tissue })}{\text { MDA }}$} & Mean & 135.0 & 179.2 & 147.3 & 184.7 & 163.0 & 198.0 & 175.2 & 240.3 & 181.6 \\
\hline & $\begin{array}{c} \pm \\
\text { S.E }\end{array}$ & $\begin{array}{c} \pm \\
2.9^{a}\end{array}$ & $\begin{array}{c} \pm \\
1.2^{b}\end{array}$ & $\begin{array}{c} \pm \\
4.7^{c}\end{array}$ & $\begin{array}{c} \pm \\
2.9^{b}\end{array}$ & $\stackrel{ \pm}{4.2^{d}}$ & $\begin{array}{c} \pm \\
3.2^{\mathrm{e}}\end{array}$ & $\stackrel{ \pm}{2.5^{b}}$ & $\begin{array}{c} \pm \\
8.5^{b}\end{array}$ & $\begin{array}{c} \pm \\
3.2^{b}\end{array}$ \\
\hline & $\%$ & ----- & 32.7 & 9.1 & 36.8 & 20.7 & 46.6 & 29.7 & 78 & 34.5 \\
\hline \multirow{3}{*}{$\begin{array}{c}\text { SOD } \\
\text { (U/g tissue) }\end{array}$} & Mean & 1192.7 & 932 & 998 & 835.7 & 728 & 802.7 & 842.1 & 757 & 832 \\
\hline & $\begin{array}{c} \pm \\
\text { S.E }\end{array}$ & $\begin{array}{c} \pm \\
51^{\mathrm{a}}\end{array}$ & $\begin{array}{c} \pm \\
26.4^{b, c}\end{array}$ & $\begin{array}{c} \pm \\
7.6^{\mathrm{a}, \mathrm{b}}\end{array}$ & $\stackrel{ \pm}{38.2^{b, c}}$ & $\begin{array}{c} \pm \\
206^{c}\end{array}$ & $\begin{array}{c} \pm \\
35.3^{b, c}\end{array}$ & 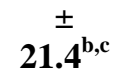 & $\begin{array}{c} \pm \\
27.8^{c}\end{array}$ & $\begin{array}{c} \pm \\
33.9^{b, c}\end{array}$ \\
\hline & $\%$ & ------ & -21.8 & -16.3 & -29.9 & -38.9 & -32.6 & -29.3 & -36.5 & -30.2 \\
\hline \multicolumn{11}{|c|}{$\begin{array}{l}\text { Each value represented means of } 5 \text { records } \pm \text { S.E. } \\
\text { a,b,c,d.e means comparison between all groups which the groups have the same letter mean there is no significance difference and which } \\
\text { have different letter mean there is a significance change. } \\
\% \text { : Percent of changes from control values. }\end{array}$} \\
\hline
\end{tabular}

\section{Discussion:-}

A fundamental goal of ecotoxicology and hazard assessment is to determine the ecological effects of toxic chemicals on natural communities and ecosystems. Little information exists regarding the toxicity of pendimethalin to fish. There has been increasing interest in the use of fish as biomarkers for the effects of pollution and for the early detection of aquatic environmental contamination (van der Oost et al., 2003and EL-Sayed et al., 2013) so, Aquatic environments are commonly impacted by various pesticides (including herbicides, fungicides, and insecticides) from different sources. Fish species are described as suitable monitors for the effects of noxious compounds because of their ecological and economical relevance(Jiraungkoorskulet al., 2002 and Moustafaet al., 2016). In addition, changes in haematological, biochemical and cellular levels are among the most sensitive biological responses 
reported after fish exposure to aquatic pollutants (Sandriniet al., 2013 andMoustafaet al., 2016).The Present study was directed to investigate the behavioral, haematological, biochemical, antioxidants and oxidative stress effects of Pendimethalin(Stomp) herbicide on Nile catfish (Clarias gariepinus). The initial reaction of the catfish was observed in the present study is swim actively due to the effect on the nervous system; the rapidity of swimming was directly proportional to the concentration of the chemical. The stressful and erratic behaviors of the (Clarias gariepinus) also tend to indicate respiratory impairment probably due to the effect of the chemical on the gills. Fish breathe by movement of water, dissolved oxygen and any water contaminants present, in and out through their gills, so the gills are usually site of first contact of the internal organ. The observed behavioral changes and clinical toxicity signs in catfish are in agree with those reported by Ahmed and Moustafa, (2010)inwhich the abnormal behavioral changes in the fish mainly manifested in their respiratory and nervous systems, and appeared immediately after exposure to pendimethalin. The abnormal movements may have resulted from hypercontractions of the muscles due to cholinesterase inhibition at the highest pendimethalin concentration (El-Sharkawyet al., 2011) in addition the respiratory manifestations may have resulted from excess mucus secretions forming a thick coating on the gill tissue (Ferguson, 1989 and Attallah et al., 1997).El- Sharkawyet al., (2011) found that the introduction of Stomp herbicide into the aquatic system impaired respiration and the fish often found dead with open mouths attributing these observations to the inert components of the herbicide; as petroleum solvents (naphthalene and ethylene dichloride).

Under the stressful conditions, the catfish become hyperactive and thus require large amounts of oxygen to achieve the requirements of energy also, secrete large amounts of mucous to coat their body especially on the gills to gain relief from the irritating effects of toxicants ( Pandey et al., 2009 and Ahmed, 2011). This results are in agreement with Auta and Ogueji, (2007); Okomoda and Ataguba, (2011);Marzouket al.,(2012) and EL-Sayed et al.,(2013).

As fish are in direct contact with the environment, only a thin epithelial membrane separates the blood of the fish from water (HlaveandBulkey, 1980). As a matter of fact, blood is a pathophysiological reflector of the body because it is highly susceptible to internal and external environmental fluctuations. Morphological changes in blood indicate the changes in the quality of the environment and therefore the functional status of the animal exposed to toxicants (Seth andSaxena, 2003). Knowledge of the haematological characteristics is an important tool that can be used as an effective and sensitive index to monitor physiological and pathological changes in fishes and the exposure of chemical pollutants can induce either increase or decrease in haematological level eosinophils (Hawkins and Mawdesley, 2006; Schlenket al., 2008; Alohanet al., 2014 and Nwani et al., 2015).

Fish live in a very close contact with their environment, and therefore they are very vulnerable to any physicochemical changes which may be reflected in their blood parameters Wilson and Taylor, (1993) andNdimeleet al., (2015). The obtained data showed a significant increase in RBCs, hemoglobin, hematocrits, blood indices and WBCs count in groups exposure to pendimethalin herbicide when compared to the corresponding values in control group and this may be due to it appears that the presence of greater amounts of herbicides in waters may exert a greater and more lasting effect on the hematological profile of fish. The results may also be indicative of the synergistic action of the Pendimethalin herbicide. Also this may due to haemo-concentration and polycythemia due to decrease the amount of dissolved oxygen in water or may due to Hemochromatosis in which too much iron RBCs and haemoglobin in the body causes hemochromatosis. Iron is important because it is part of hemoglobin, a molecule in the blood that transports oxygen from the lungs to all body tissues. iron may build up in the organs and cause complications, including cirrhosis, or scarring of liver tissue , diabetes, irregular heart rhythms or weakening of the heart muscle, arthritis and erectile dysfunction. The complication most often associated with hemochromatosis is liver damage. Iron buildup in the liver causes cirrhosis, which increases the chance of developing liver cancer (Bacon $\boldsymbol{e t}$ al., 2011). These results are in agreement with those observed by (Velisek $\boldsymbol{e t}$ al., (2009), Velisek et al., (2011), Nascimentoet al., (2012) and EL-Sayed et al., 2013). Also, this results are in agreement with Oloruntuyiet al., (2000) who reported that herbicides cause changes in the quality of water in and near sprayed areas as decrease in dissolved oxygen in the water, along with an increase in temperature, may pose threat to the survival of fish species after herbicide applications. The calculated blood indices, MCV, MCH \& MCHC have particular importance in describing anemia in most animals and the increase in MCV may be attributed to the direct effect of catecholamines, cortisol, and glucose on adenylate cyclase activities in red blood cells, as a response to acute hypoxic stress (Coles et al.,1986andSalehet al., 2016).Moreover, general decrease in $\mathrm{MCH}$ and MCHCcould be attributed to RBCs haemolysis and the reduction of RBCsproduction in the haemopoietic tissues under the action of the bio-accumulated herbicide as indicated. 
In our study, data showed a significant increase in WBCs count in catfishes treated with $5 \%$ and $10 \%$ of pendimethaline for 7 and 21 days when compared to the corresponding values in control group and this may due to activate the immune system or due to stress in fish by change in WBCs count and convert to leucocytosis. Leucocytes are involved in the regulation of immunologicalfunctions and protective response to stress in fish (Velisek et al., 2012). This results in agreement withZaahkouket al., (1996); (Ayubet al.,1997); Haggag (2004) andModesto and Martinez, ( 2010) whoreportedthat Pendimethalin herbicide mayactivate the immune system in fish by alteringlevels of totalleukocytes, thussignaling an adaptive immune response. In addition, the increaseinWBCsmayreflect the proliferation of multipotenthematopoieticcells as a consequence of chemicaltoxicity(Fink andSalibian, 2005) the increase in WBCsindicatesthat thestress condition of the fishinduced by pendimethalin maycausehypoxia and gill damage. Thus, the increase in WBCs count indicate to the stress condition of fishinduced by expossure to Stomp herbicide thatmay have producedhypoxia and gill damage ( ELSayed et al., 2013).

Increase in WBCs count occurred as a pathological response since these WBCs play a great role during infestation by stimulating the haemopoietic tissues and the immune system by producing antibodies and chemical substances working as defense against infection (Wedmeyer and Wood, 1974; Lebeloet al., 2001; Hassen, 2002 and Masud and Singh, 2013). WBC is important cells in the immune system, because of their main defensive function. The WBCs respond immediately to the change in medium due to xenobiotic transformation. During toxic exposure period of herbicide, the WBCs counts were enhanced. It indicates that fish can develop a defensive mechanism to overcome the toxic stress. The leukocyte profile can also be affected by different kinds of pesticides in which the present study revealed a significant increase in the number of lymphocytes this may be due to the addition of EDTA improves the haematological which can be attributed to the capability of EDTA to chelate or remove from the media and subsequently, the Pendimethalin toxicity was reduced . and this is agree with (Modesto and Martinez, 2010) in which their results revealed a significant increase in the number of lymphocytes and a reduction in the number of neutrophils after exposure to the herbicide. In our study, data showed a significant decrease in platelets count in catfishes treated with pendimethalin when compared to the corresponding values in control group and this may due to induce hepatic histological changes and bleeding and this may affect coagulation factors and clotting and this results in agreement with (Neiva et al., 2010) whoobserved that the results demonstrate that herbicide caused changes in the platelet metabolism with an inhibitory effect on primary hemostasis and the longterm treated of rats with low doses of herbicidemay induce hepatic histological changes, the leakage of hepatic intracellular enzymes such as alanine aminotransferase and aspartate aminotransferase as well as nasal bleeding. Also, Thrombocytopenia is more likely to occur in the presence of hypersplenism associated with liver cirrhosis (Bashouret al., 2000andTefferiet al., 2005). The addition of EDTA improves the haematological parameters as platelets which can be attributed to the capability of EDTA to chelate toxic substance from the media and subsequently, the herbicide toxicity was reduced (Shalabyet al., 2011).

\section{Biochemical parameters:}

Measurements of biochemical alterations have been used to monitor the environmental exposure of fish to contaminants in both laboratory and field studies (Shailaja and D'Silva, 2003), because of the sensitivity of fish to the adverse effects of xenobiotics (Ahmad et al., 2004). The obtained data showed a significant increase in serum ALAT, ASAT, ALP , GGT enzymes activity, total protein, albumin and globulin levels in catfishes treated with pendimethaline when compared to the corresponding values in control group and this may be due to increase in activities of these enzymes, reflecting the damage of the liver cells or changes in the cell membrane permeability leading to leakage of enzymes from cells to the circulation (Botsoglouet al., 2008). These results are in agreement with Abd-algadiret al., (2011) and El-Sharkawyet al., (2011) reported that Pendimethalin significantly increased serum ALAT, ASAT, ALP in fish exposed to Pendimethalin and this may due to damage of hepatocytes.

Akila et al., (1998) who assessment of liver function can be made by estimating the activities of serum SGOT, SGPT and ALP, which are originally present in higher concentration in the cytoplasm. Hepatocellular necrosis leads to the elevation of these serum marker enzymes, which are released from the liver into the blood stream (Shenoyet al., 2002). The increased levels of S.GOT, S.GPT, and S.ALP are conventional indicator of liver injury (Achliyaet al., 2004).

Hence, the elevated activities of serum ASAT and ALAT indicate liver damage or enhanced transamination. Increased transamination during herbicide challenge has been attributed to the need to meet higher energy demanded by fish (Natarajan, 1985 and Philip et al., 1995). Proteins are the most important and abundant macromolecules in 
living organisms, which play a vital role in architecture and physiology of the cell and in cellular metabolism (Mommsen and Walsh, 1992). Also serum total protein play an important role in the maintenance of osmotic balance between the circulating blood and the tissue membrane.

Results revealed hyperproteinemia, hyperglobulinemia and hyperalbuminemia in catfish exposure to Pendimethalin in comparison to the control group, this result may be due to indicate elevated liver metabolic activity and proteins and albumin may be elevated due to dehydration albumin likely to be elevated alsochronic infection / inflammation e.g. osteomyelitis, endocarditis, autoimmune disorders e.g. rheumatoid disease, systemic lupus erythematosus (but not 'organ-specific' autoimmune diseases, excepting autoimmune hepatitis, para-proteinaemia (myeloma and other causes). Also, total globulin raised in patients with autoimmune disease, chronic inflammation and paraproteinaemia(Marshall, W. 2012) this results in agreement with (EL-Sayed et al., 2013) who recorded that the increased total protein content of fish individuals exposed to pendimethalin is mainly attributed to increased globulin levels, which indicate elevated liver metabolic activity (Peixotoet al., 2006), and which is considered as another adaptive response to toxicity.

Glusczaket al., (2007) who recorded a marked increase in serum total protein level of silver catfish, $\boldsymbol{R}$. quelen exposed to glyphosate herbicide. From the other hand, Moraeset al., (2009) and Velisek et al., (2011) recorded no significant changes in serum total protein and albumin concentrations of (Leporinusobtusidens) and (Cyprinuscarpio)exposed to $(376 \mu \mathrm{g} / \mathrm{l})$ clomazone herbicide and $(0.2$ and $2 \mu \mathrm{g} / \mathrm{l})$ terbutryn for 90 days and 28,90 days, respectively. This may be attributed to different tested chemicals and the differences in exposure periods or fish species.

\section{Heart functions test and glucose:-}

The obtained data showed a significant increase in CPK and LDH enzyme activity in all catfish groups exposed to herbicide when compared to the corresponding values in control group. Creatinephospho kinase (CPK) is an enzyme found in muscle, heart, gills and brain (Banaeet al., 2014). This results in agreement with(Abbas et al., (2007); Veliseket al., (2009) and Doubeket al., (2010).

Creatine phosphokinase is an intracellular enzyme that catalyzes the formation of adenosine triphosphate (ATP) from creatine phosphate and adenosine diphosphate (ADP). It is therefore abundant in metabolically active tissues with significant energy demands, specifically skeletal and smooth muscle, myocardium, and brain. Three distinct isoenzyme forms of CPK have been identified, namely, CPK-MM, MB, and BB ( $\mathrm{M}$ - muscle, B-brain) recently, One of the several biochemical markers that have been studied in an effort to improve early detection of ectopic pregnancy is creatine phosphokinase (CPK) Lott and Albott, (1986) and Kruchkovichet al., (2012) .

The enzymes lactate dehydrogenase (LDH) and creatinphospho kinase (CPK) are metabolic key factors (Ocamposet al., (1987); Gill et al., (1990); Coppes, (1992); Pelletier et al., (1994); Gilliet al., (2000); Kurutas and Tuncer, (2000); Leopold and Loscalzo, ( 2000); Long et al., (2003) and Osman et al.,(2007) . The cytoplasmic enzyme LDH is widely used as marker of organ or tissue lesions in toxicology and in clinical chemistry and It has been used for demonstrating tissue damage in fish (Das et al., 2004a). In most cases of tissue damage, whether due to disease or toxic compound, the activity of LDH was reported to be significantly affected (Singh and Sharma, 1998). LDH is a source of the oxidised coenzyme during the period of transient anaerobiosis or a reduced form of such coenzyme during aerobiosis(Coppes, 1992). LDH plays an important role during glycolysis, and have direct effects on the development of fish (Shaklee $\boldsymbol{e t}$ al., 1974). Elevated levels of this enzyme in plasma indicate a transient damage to either muscle fibers( cardiac) or other tissues in which the continuous exposure to acute herbicide concentrations resulted in significantly increased levels of CK in common carp at 96 . increased activity of $\mathrm{CPK}$ and LDH can be explained as a consequence of pathological changes in hepatic tissue . Catalytic activities of plasma enzymes (i.e. LDH, CK, ALT, and AST) may be used as indicator of stress reaction as the increased values indicate stress-based tissue impairment.

\section{Oxidative stress and antioxidants:-}

A significant decrease in the liver catalase (CAT), superoxide dismutase (SOD), glutathione reductase (GR) activity and reduced glutathione (GSH) in catfish groups treated with Pendimethalin when compared to the corresponding values in control group this may be due to decreased synthesis of (GSH) in the tissues, thereby preventing the maintenance of the homeostatic redox status in the presence of the oxidative effects that occurred after exposure to Pendimethalin. Pendimethalin also reduced (CAT) and (SOD) levels, possibly because of decreases in the rates of 
(CAT) and (SOD) reactions as a result of peroxidative damage to the liver.Regarding the effects of Pendimethalin on oxidative stress status in the liver of catfish our results indicate that Pendimethalin increased LPO and decreased levels of GSH and activities of antioxidant enzymes, especially of CAT, SOD, and GR. The herbicide significantly $(\mathrm{p}<0.05)$ decreased the GSH content and activities of CAT, GR, and SOD, and increased the MDA content in the liver.

The depletion of hepatic and gill GSH may increase oxidative stress (Luo et al., 2005); thus, the decreased GSH content in the tissue may have resulted from the consumption of GSH to reduce oxidative stress (Sharbidreet al., 2011), as reflected in the increased MDA level, under the influence of Pendimethalin.

Moreover, the reduction in GR activity may have resulted in decreased synthesis of GSH in the tissues, thereby preventing the maintenance of the homeostatic redox status in the presence of the oxidative effects (Atli and Canli, 2010) that occurred after exposure to pendimethalin. Pendimethaline also reduced CAT and SOD levels, possibly because of decreases in the rates of CAT and SOD reactions as a result of peroxidative damage to the liver and gills, and/ or excess production of ROS, as is observed in toxicity tests on freshwater fish using the herbicides clomazone(Crestaniet al., 2007); Lambda cyhalothrin(Saravananet al., 2008) and atrazine (Nwaniet al., 2010). Another explanation for the increase in LPO may be that pendimethalin depletes the GSH content of tissues, which may increase the risk of oxidative stress (Luo et al., 2005) and that reduced activities of CAT, SOD, and GR, which are the first barriers against ROS, are essential for cell survival. our results are consistent with studies indicating that CAT and SOD levels decrease in fish exposed to herbicides (Pandey et al., (2001); Sayeed et al., (2003); Crestaniet al., (2007); (Atli and Canli, 2010) and EL-Sayed et al., (2013).

\section{Conclusion:-}

We conclude that pendimethalin is moderately toxic to Nile catfish. The herbicide compound induces leukocytosis as a stress response to acute exposure. Pendimethalin is also capable of inducing disturbances in the antioxidant system in a time-dependent manner, and thus oxidative stress and LPO are proposed mechanisms of the physiological response of the fish to exposure. In turn, their toxicity can end up in humans through the food chain. The suitable controlled and regular use of herbicides is recommended, to obtain the beneficial effects of these resources without polluting the environment and without leaving their residues in food and water sources with potentially negative effects on human health.

\section{References:-}

1. Abd-algadir, M. I., Idris O. F. and Elkhier M. K. S. (2011): Effect of pendimethalin herbicide on fish (Tilapia nilotica) skeletal muscles, gills and its influence on human. World J Life Sci Med Res, 1, 5-10.

2. Abbas, H. H; Authman, M. M; Abumourad, I. and El-badawy, A. (2007): Studies on the effect of thiobencarb herbicide on some biological, physiological, biochemical, histological and genetic aspects of Nile tilapia, Oreochromisniloticus.Egypt. J. Aquat. Biol. \& Fish, 11(1), 123-150.

3. Achliya, G. S., Wadodkar, S. G., and Dorle, A. K. (2004): Evaluation of hepatoprotective effect of amalkadighrita against carbon tetrachloride e induced hepatic damage in rats.J. Ethnopharmacol, 90(2-3):229232.

4. Aebi, H. (1984): Catalase in vitro methods in enzymology (Ed.B. J. Willam). New Yourk, ABD 105: 121126.

5. Ahmad, I., Pacheco, M. and Santos, M.A. (2004): Enzymatic and nonenzymatic antioxidants as an adaptation to phagocyte-induced damage in Anguilla anguilla L. following in situ harbor water exposure. Ecotoxicol Environ Saf 57:290-302.

6. Ahmed, E. N. G. and Moustafa, G. G. (2010): Evaluation the Toxic Effects of Herbicide Stomp 50\% EC (Pendimethalin) On Health of Oreochromisniloticus. Zag. Vet. J. (ISSN. 1110-1458), 38(3), 8-17.

7. Ahmed, Z. (2011):Acute toxicity and haematological changes in common carp (Cyprinuscapio) caused by diazinonexposure.Afr J Biotechnol, 10(63): 13852-13859.

8. Akila, G., Rajakrishnan, V., Viswanathan, P., Rajashekaran, K. N., and Menon, V. P. (1998): Effects of curcumin on lipid profile and lipid peroxidation status in experimental hepatic fibrosis. Hepatology Research 11(3):147-157.

9. Allain, C., Poon, L., Chan, C., Richmond, W., and Fu, P. (1974): Enzymatic determination of total serum cholesterol. Clin. Chem., 20(4):470-475. 
10. Almeida, J. A., Diniz, Y. S., Marques, S. F. G., Faine, L. A., Ribas, B. O., Burneiko, R. C. and Novelli, E. L. B. (2002): The use of the oxidative stress responses as biomarkers in Nile tilapia (Oreochromisniloticus) exposed to in vivo cadmium contamination. Environment International, 27(8), 673-679.

11. Alohan, F .I .; Erhunmwunse, N . O.; Ainerua, M . O .and Ewere, E. E. (2014): Haematological Indices in Fish Plasma as Indicators of Exposure to a Commonly Used Herbicdes. Aust. J. Basic \& Appl. Sci., 8(6): 245$250,2014$.

12. Anwar, W.A. (2003): Environmental health in Egypt. International journal of hygiene and environmentalhealth, 206, 339-350.

13. Atli, G. and Canli, M. ( 2010): Response of antioxidant system of freshwater fish Oreochromisniloticus to acute and chronic metal exposures. Ecotoxicol Environ Saf 73:1884-1889.

14. Attallah, O. A., Ali, A.M., Ibrahim, A.S. and Sakr, S.F.(1997): Prevalence of pathologic changes associated with the fin - rot- indicating bacterial disease in freshwater fish. Alex J Vet Sci, 73(6): 629-644.

15. Auta, J., and Ogueji, E. O. (2007): Acute Toxicity and behavioural effects of chlorpyrifos-Ethyl pesticide to juvienile of Clarias gariepinus Teugels. Procceeding, 22nd Annual Comference of Fisheries Society of Nigeria (FISON) held at School of Nursing, BirninKebbi, 12th-16th November, 2007, $264-272$.

16. Ayub, S. M., Garg, S. K., and Garg, K. M. (1997): Sub-acute toxicity studies on pendimethalin in rats. Indian Journal of Pharmacology, 29(5), 322.

17. Bacon, B. R., Adams, P. C., Kowdley, K. V., Powell, L. W., and Tavill, A. S. (2011): Diagnosis and management of hemochromatosis: 2011 practice guideline by the American Association for the Study of Liver Diseases. Hepatology, 54(1), 328-343.

18. Banaee, M., Davoodi, M. H. and Zoheiri, F. (2014): Histopathological changes induced by paraquat on some tissues of gourami fish (Trichogastertrichopterus). Open veterinary journal, 3(1), 36-42. ISO 690.Barton, B.A. and Iwama, G.K. (1991): Physiological changes in fish from stress in aquaculture with emphasis on the response and effects of corticosteroids. Ann. Rev. Fish Dis., 1, 3-26.

19. Bashour, F. N., Teran, J. C. and Mullen, K. D. (2000): Prevalence of peripheral blood cytopenias (hypersplenism) in patients with nonalcoholic chronic liver disease. The American journal of gastroenterology, 95(10), 2936-2939.

20. Bergmeyer, H.U., Horder, M., and Rej, R. (1986): International federation of clinical chemistry (IFCC) method for aspartate aminotransferase. J. Clin. Chem. Clin. Biochem. 24:481-495.

21. Beutler, E., Duron, O., and Kelly, B. M. (1963): Improved method for the determination of blood glutathione. J. Lab. Clin. Med., 61(5):882-888.

22. Blaurock-Busch, E., and Busch, Y. M. (2014): Comparison of Chelating Agents DMPS, DMSA and EDTA for the Diagnosis and Treatment of Chronic Metal Exposure. British Journal of Medicine and Medical Research, 4(9), 1821-1835.

23. Botsoglou, N. A., Taitzoglou, I. A., Botsoglou, E., Lavrentiadou, S. N., Kokoli, A. N., and Roubies, N. (2008): Effect of long-term dietary administration of oregano on the alleviation of carbon tetrachloride induced oxidative stress in rats. J. Agric. Food Chem., 56(15):6287-6293.

24. Canli, M. and Kalay, A. (1998): Level of heavy metals ( $\mathrm{Cd}, \mathrm{Pb}, \mathrm{Cu}, \mathrm{Cr}$ and $\mathrm{Ni}$ ) in tissue of Cyprinuscarpio, BarbuscapitoandChondrostomaregiumfrom the Seyhan River, Turkey. Turkish journal of zoology, 22, 149157.

25. Chrouses, G.P. (1998): Stressors, stress and neuroendocrine integration of the adaptative response. Ann. NY. Acad. Sci. 851:311-335.

26. Coles, E.H. (1986): Veterinary Clinical Pathology. W.B. Saunders, Philadelphia, pp. 10-42. Cornelius, C.E., 1991. Bile pigments in fishes: A review. Vet. Clin. Pathol. 20, 106-116.

27. Coppes, Z. (1992): Lactate-dehydrogenase in teleosts-the role of ldh-C4 isozyme. Comp BiochemPhysiol B 102:673-677.

28. Crestani, M.; Menezes, C.; Glusczak, L.; dos Santos Miron, D.; Spanevello, R.; Silveira, A.; Goncalves, F.F.; Zanella, R. and Loro, V.L. (2007): Effect of clomazone herbicide on biochemical and histological aspects of silver catfish (Rhamdiaquelen) and recovery pattern. Chemosphere 67:2305-2311.

29. Das, P.C., Ayyappan, S., Das, B.K. and Jena, J.K. (2004a): Nitrite toxicity in Indian major carps: sublethal effect on selected enzymes in fingerlings of Catlacatla, Labeorohita and Cirrhinusmrigala. Comp BiochemPhysiol C 138:3-10.

30. Dods, R. F. (2003): Diabetes mellitus clinical chemistry: theory analysis, correlation. $\mathbf{4}^{\text {th }}$ Edition, Kaplan, L. A., Pesce, A. J., and Kazmierczak, S. C. 580. 
31. Doubek, J., Slosarkova, S., Rehakova, K., Bouda, J., Scheer, P., Piperisova, I. and Matalova, E. (2010): The interpretation of basic biochemical and haematological indices in animals. Noviko, Czech Republic (in Czech).

32. Doumas, B.T., Watson, W. A. and Biggs, H.G. (1971): Albumin standards and the measurement of serum albmin with bromocresol green. Clin. Chem. Acta. 31: 87-96.

33. El-Sayed, Y. S., Samak, D. H., Abou-Ghanema, I. Y., and Soliman, M. K. (2013): Physiological and oxidative stress biomarkers in the freshwater monosex Nile tilapia, Oreochromisniloticus L., exposed to pendimethalin-based herbicide. Environmental toxicology, 30(4), 430-438.

34. El-Sharkawy, N. I., Reda, R. M., and El-Araby, I. E. (2011): Assessment of Stomp (Pendimethalin) toxicity on Oreochromisniloticus. Journal of American Science, 7(10).

35. Erhunmwunse, N. O., and Ainerua, M. O. (2013): Characterization of Some Blood Parameters of African Catfish (Clarias gariepinus). American-Eurasian Journal of Toxicological Sciences 5 (3): 72-76, 2013. ISSN 2079-2050. DOI: 10.5829/idosi.aejts.2013.5.3.82159.

36. Farombi, E. O., Ajimoko, Y. R. and Adelowo, O. A. (2008): Effect of Butachlor on antioxidant enzyme status and lipid peroxidation in fresh water African Catfish, (Clarias gariepinus). International journal of environmental research and public health, 5(5), 423-427.

37. Fatima, M., Ahmad, I.I., Sayeed, I.I., Athar, M. and Raisuddin, S.(2000): Pollutant-induced over-activation of phagocytes is concomitantly associated with peroxidative damage in fish tissues. AquatToxicol, 49(4): 243250.

38. Ferguson, H.W. (1989): Textbook of Systemic Pathology of Fish. Iowa, Canada: Iowa State .

39. Fink, N. E. and Salibián, A. (2005) : Toxicological studies in adult amphibians: effects of lead.Applied Herpetology, 2(3), 311-333.

40. German Society for Clinical Chemistry. (1972): Standard method for determination of alkaline phosphatase (AP) activity. J. Clin.Chem. Clin. Biochem. 10: 290.

41. Gill, T.S., Tewari, H. and Pande, J. (1990): Use of the fish enzyme system in monitoring water qualityeffects of mercury on tissue enzymes. Comp BiochemPhysiol C 97:287-292.

42. Gilli, M.R.M.S., Ocampos, D., Pugine, S.M.P., Lavandeira, L., Cerqueira, C.M., Rosa, R. and Bacila, M.(2000): The effect of metal ions, oxalate and amino acids on the activity of pyruvate kinase from Curimbata (Prochiloduslineatus(epaxial muscle. Arch Vet Sci 5:73-79.

43. Glusczak, L., dos Santos Miron, D., Moraes, B. S., Simões, R. R., Schetinger, M. R. C., Morsch, V. M., and Loro, V. L. (2007): Acute effects of glyphosate herbicide on metabolic and enzymatic parameters of silver catfish (Rhamdiaquelen). Comparative Biochemistry and Physiology Part C: Toxicology and Pharmacology, 146(4), 519-524.

44. Glusczak, L., dos Santos, Miron. D., Crestani, M., Braga, da Fonseca. M., de Araujo, Pedron. F., Duarte, M.F. and Vieira, V.L. ( 2006): Effect of glyphosate herbicide on acetylcholinesterase activity and metabolic and hematological parameters in piava (Leporinusobtusidens.Ecotoxicol Environ Saf 65:237-241.

45. Goldberg, D.M, Spooner, R.J. (1983): Assay of glutathione reductase. In: Bergmeyen HV, editor. Methods of Enzymatic Analysis, 3rd ed. Vol 3, VerlagChemie: Deerfield Beach, FL. pp 258- 265.

46. Gornall, A.C., Bardwill, C.J., and David, M.M. (1949): Determination of serum proteins by means of the biuret reaction. J. Biol. Chem. 177: 751-766.

47. Haggag, N.Z. (2004): Physiological studies on the changes induced by some non - traditional pesticides to the Nile catfish. M.V.Sc. thesis. Girls college, Ain shams Univ., Cairo.

48. Hardersen, S. and Wratten, S. D. (1998): The effects of carbaryl exposure of the penultimate larval instars of Xathocnemiszealandica on emergence and fluctuating asymmetry. Ecotoxicology, 7(5), 297-304.

49. Hassen, F.E.Z. (2002): Studies on diseases of fish caused by Henneguya infestation, Ph.D Thesis, Faculty of Veterinary Medicine, Suez Canal University. Egypt.

50. Hawkins, R.I. and Mawdesley, T.L. (2006): Fish haematology - a bibliography. J. Fish. Biol., 4:193-232.

51. Hermes-lima, M.(2004): Oxygen in biology and biochemistry: role of free radicals. In : storey k .B. (Ed.) Functional metabolism: regulation and adaptation. John Wiley and Sons, Inc., Hoboken, New Jersey, USA. Pp. 319-368.

52. Hlavek, R.R. and Bulkey, R.V. (1980): Effects of malachite green on leuckocyte abundance in Rainbow trout; Salmo garidberi(Richardson). J. Fish.Biol., 17: 431-444.

53. Huska, D.; Krizkova, S.; Beklovah, M.; Havel, L.; Zenalek, J.; Diopan, V.; Adam, V.; Zeman, L.; Babula, P. and Kizek, R. (2008): Influence ofCadmium (11) ions and brewery sludge on themetallothionein level in earthworm (Eseniafetida) - Biotransforming of toxic wastes. Sensors. 8., 1039- 1047. 
54. Jacobs, M. N., Covaci, A. and Schepens, P. (2002): Investigation of selected persistent organic pollutants in farmed Atlantic salmon (Salmo salar), salmon aquaculture feed, and fish oil components of the feed. Environmental science \& technology, 36(13), 2797-2805.

55. Jiraungkoorskul, W., Upatham, E. S., Kruatrachue, M., Sahaphong, S., Vichasri-Grams, S. andPokethitiyook, P.(2002):Histopathological effects of Roundup, a glyphosate herbicide, on Nile tilapia (Oreochromisniloticus).ScienceAsia, 28: 121-127.

56. Kadenbach, B., Ramzan, R. and Vogt, S. (2009): Degenerative diseases, oxidative stress and cytochrome c oxidase function.Trends. Mol. Med., 15(4):139-147.

57. Klip, A., and Vranic, M. (2006): Muscle, liver and pancreas: Three Musketeersfighting to control glycemia.Am. J. Physiol. Endocrinol. Me Tab., 291(6):1141-1143.

58. Kruchkovich, J., Orvieto, R., Fytlovich, S., Lavie, O., Anteby, E. Y. and Gemer, O. (2012): The role of CPK isoenzymes in predicting extrauterine early pregnancy. Archives of gynecology and obstetrics, 286(1), 135-137.

59. Kurutas, E.B. and Tuncer, I. (2000): A mouse model for evaluating the induction of liver glucose-6phosphate dehydrogenase by halothane. Turk J Vet AnimSci 24:511-515.

60. Lebelo, S. L; Saunders, D. K; Crawford, T. G. (2001): Observations on blood viscosity in striped bass, Moronesaxtilis (Walbaum) Associated with fish Hatchery conditions. Kansa Acad. Sci. 104: 183-194.

61. Leopold, J.A. and Loscalzo, J. (2000): Cyclic strain modulates resistance to oxidant stress by increasing G6PDH expression in smooth muscle cells. Am J Physiol. 279:H2477-H2485.

62. Li, W.M; Yin, D.Q ; Zhou, Y; Hu, S.Q. and Wang, L. S. (2003): 3,4-dichloroaniline-induced oxidative stress in liver of crucian carp (Carassiusauratus). Ecotoxical Environ Saf, 56(2): 251-255.

63. Livingstone, D.R. (2001). Contaminantstimulated Reactive Oxygen Species Production and Oxidative Damage in Aquatic Organisms. Marine Pollution Bulletin, Vol. 42, pp.

64. Long, S.M., Ryder, K.J. and Holdway, D.A: (2003): The use of respiratory enzymes as biomarkers of petroleum hydrocarbon exposure in Mytilus edulis planulatus.Ecotox Environ Safe 55:261-270.

65. Lott, J.A. and Albott, L.B. (1986): Creatine kinase isoenzymes. Clin Lab Med 6:547-576.

66. Luo, Y., Wang, X. R., Shi, H.H., Mao, D.Q., Sui, Y.X. and Ji, L.L. (2005): Electron paramagnetic resonance investigation of in vivo freeradical formation and oxidative stress induced by 2,4-dichlorophenolin the freshwater fish Carassiusauratus. Environ ToxicolChem 24:2145-2153.

67. Luo, Y., Wang, X. R., Shi, H.H., Mao, D.Q., Sui, Y.X. and Ji, L.L. (2005): Electron paramagnetic resonance investigation of in vivo freeradical formation and oxidative stress induced by 2,4-dichlorophenolin the freshwater fish Carassiusauratus. Environ ToxicolChem 24:2145-2153.

68. Malins, D. C. and Ostrander, G.K. (1991): Perspectives in aquatic toxicology. Annu Rev PharmacolToxicol 31:371-399.

69. Marshall, W. (2012): Name and description of analyte Total protein. Association for Clinical Biochemistry 2012.

70. Marzouk, M. S., Kadry, S. M., Amer, A. M., Hanna, M. I., Azmy, I. H. and Hamed, H. S. (2012): Effect of atrazine exposure on behavioral, haematological and biochemical aspects of female African catfish (Clarias gariepinus). J. Sci. Res.102/305.

71. Masud, S and Singh, I. J. (2013): Effect of Cypermethrin on some hematological parameters and prediction of their recovery in afreshwater Teleost, (Cyprinuscarpio), Vol. 7(9), pp. 852-856, ISSN 1996-0786, 2013 Academic Journals.

72. Modesto, K.A. and Martinez, C.B. (2010): Effects of Roundup Transorb on fish: hematology, antioxidant defenses and acetylcholinesterase activity. Chemosphere 81:781-787.

73. Modesto, K.A. and Martinez, C.B. (2010): Effects of Roundup Transorb on fish: hematology, antioxidant defenses and acetylcholinesterase activity. Chemosphere 81:781-787.

74. Mommsen, T. P., and Walsh, P. J. (1992): Biochemical and environmental perspectives on nitrogen metabolism in fishes. Experientia, 48(6), 583-593.

75. Monteiro, D. A., De Almeida, J. A., Rantin, F.T. and Kalinin, A.L. (2006): Oxidative stress biomarkers in the freshwater characid fish, Bryconcephalus, exposed to organophosphorus insecticide folisuper 600 (methyl parathion). Comp biochem and toxicolpharmacol, 142(2): 141-149.

76. Moraes, B. S., Loro, V. L., Glusczak, L., Pretto, A., Menezes, C., Marchezan, E. and de Oliveira Machado, S. (2007): Effects of four riceherbicides on some metabolic and toxicology parameters of teleost fish (Leporinusobtusidens). Chemosphere 68:1597-1601. 
77. Moraes, B.S.; Loro, V.L.; Pretto, A.; da Fonseca, M.B.; Menezes, C.; Marchesan, E;.Reimche, G.B. and de Avila, L.A. (2009): Toxicological and metabolic parameters of the teleost fish, Leporinusobtusidens in response to commercial herbicides containing clomazone and propanil. Pest. Biochem. Physiol., 95: 57 -62.

78. Moustafa, G. G., Shaaban, F. E., Hadeed, A. A. and Elhady, W. M. (2016):Immunotoxicological, biochemical, and histopathological studies on Roundup and Stomp herbicides in Nile catfish (Clarias gariepinus). Veterinary World, 9(6), 638.

79. Nascimento, C.R.B.; Souza, M.M. and Martinez, C.B.R. (2012): Copper and the herbicide atrazine impair the stress response of the freshwater fish Prochiloduslineatus., Comp.Biochem. Physiol., 155 (C): 456-461.

80. Natarajan, G. M. (1985): Induction of branchial enzymes in snake head (Channastriatus) by oxydemetonmethyl. Pesticide biochemistry and physiology, 23(1), 41-46.

81. Ndimele, P. E., Jenyo-Oni, A., Kumolu-Johnson, C. A., Chukwuka, K. S. and Onuoha, S. (2015): Effects of acute exposure to Endosulfan (organochlorine pesticides) on hematology of African Mud Catfish, Clarias gariepinus (Burchell, 1822). Bulletin of environmental contamination and toxicology, 95(2), 164-170.

82. Neiva, T. D. J. C., Moraes, A. C. R., Schwyzer, R., Vituri, C. D. L., Rocha, T. R. F., Fries, D. M. and Benedetti, A. L. (2010). In vitro effect of the herbicide glyphosate on human blood platelet aggregation and coagulation. RevistaBrasileira de Hematologia e Hemoterapia, 32(4), 291-294.

83. Nwani, C. D., Ekwueme, H. I., Ejere, V. C., Onyeke, C. C., Chukwuka, C. O., Peace, O. S., and Nwadinigwe, A. O. (2015): Journal of Coastal Life Medicine. Journal of Coastal Life Medicine, 3(1), 35-43.

84. Nwani, C. D; Lakra, W. S; Nagpure, N. S; Kumar, R.; Kushwaha, B. and Srivastava, S. K.( 2010): Toxicity of the herbicide atrazine: effectson lipid peroxidation and activities of antioxidant enzymes inthe freshwater fish Channa punctatus (Bloch). Int. J Environ Res Public Health 7:3298-3312.

85. Ocampos, D., Rosa, C., Rodrigues, E. and Rosa, R. (1987): Purification of muscle pyruvate kinase and lactate dehydrogenase and stability of pyruvate kinase fromfish (Mugillisa and Chaetoditherusfaber). ArqBiolTechnol 29:699-705.

86. Okomoda, V. T., and Ataguba, G. A. (2011): Blood glucose response of Clarias gariepinus exposed to acute concentrations of glyphosate-isopropylammonium (Sunsate $\left.{ }^{\circledR}\right)$. Journal of Agricultural and Veterinary Sciences, 3(6), 69-75.

87. Olaifa, F. G.; Olaifa, A. and Onwude, T. (2004): Lethal and sub lethal effects of copper to the African Cat fish (Clarias garienpinus), Afr. J. Biomed. Res. 7, 65-70.

88. Oloruntuyi,O. O.,Mulero, O. and Odukale B. (2000): The effect of two pesticides on Clarias gariepinus.

89. Olufayo, M. O. and Alade, O. H. (2012): Acute toxicity and histological changes in gills, liver and kidney of catfish, Heterobranchusbidorsalis exposed to cypermethrin concentration . African Journal of Agricultural Research Vol. 7(31), pp. 4453-4459.

90. Osman, A. G., Mekkawy, I. A., Verreth, J. and Kirschbaum, F. (2007): Effects of lead nitrate on the activity of metabolic enzymes during early developmental stages of the African catfish, Clarias gariepinus (Burchell, 1822). Fish Physiology and Biochemistry, 33(1), 1-13

91. Osman, A.G.M., Al-Awadhi, R.M., Harabawy, A.S. and Mahmoud, U.M. (2010): Evaluation of the Use of Protein Electrophoresis of the African Catfish Clarias gariepinus (Burchell, 1822) for Biomonitoring Aquatic Pollution.Environmental Research Journal, 4, 235-243.

92. Pandey, S.; Ahmad, I.; Parvez, S.; Bin-Hafeez, B.; Haque, R. and Raisuddin, S. (2001): Effect of endosulfan on antioxidants of freshwater fish Channa punctatus Bloch: 1. Protection against lipid peroxidation in liver by copper preexposure. Arch Environ Contam Toxicol41:345-352.

93. Pandy, R.K., Singh, R.N., Singh, S., Singh, N.N. and Das, V.K. (2009): Acute toxicity bioassay of dimethoate on freshwater airbreathing catfish, Heteropneustesfossilis (Bloch). J of Environ Biol, 30(3): 437440.

94. Peixoto F, Alves-Fernandes D, Santos D, Fontamhas-Fernandes A. (2006): Toxicological effects of oxyfluorfen on oxidative stress enzymes in tilapia Oreochromisniloticus. Pest Biochem Phys 85:91-96.

95. Pelletier, D., Blier, P.U., Dutil, J.D. and Guderley, H.(1995): How should enzyme activities be used in fish growth studies. J ExpBiol 198:1493-1497.

96. Philip, G. H., Reddy, P. M. and Sridevi, G. (1995): Cypermethrin-induced in vivo alterations in the carbohydrate metabolism of freshwater fish, Labeorohita. Ecotoxicology and environmental safety, 31(2), 173178.

97. Porte, C. and Albaigés, J. (1994): Bioaccumulation patterns of hydrocarbons and polychlorinated biphenyls in bivalves, crustaceans, and fishes. Archives of Environmental Contamination and Toxicology, 26(3), 273281. 
98. Rosalki, S. B., Tarlow, D., and Rau, D. (1971): Plasma gamma-glutamyl trans peptidase elevation in patients receiving' enzyme-inducing drugs. The Lancet, 298(7720), 376-377.

99. Rudneva I. (2007): Agricultural aspects of aquatic environmental toxicology-A review of literature.Gigiena I Sanitariia 2: 24-28.

100.Saleh, Y. S., and Marie, M. A. S. (2016): Use of Arius thalassinus fish in a pollution biomonitoring study, applying combined oxidative stress, hematology, biochemical and histopathological biomarkers: A baseline field study. Marine pollution bulletin, 106(1), 308-322.

101.Sancho, E., Fernandez-Vega, C., Ferrando, M. D. and Andreu-Moliner, E. (2003). Eel ATPase activity as biomarker of thiobencarbexposure.Ecotoxicology and environmental safety, 56(3), 434-441.

102.Sandrini, J.Z., Rola, R.C., Lopes, F.M., Buffon, H.F,. Freitas, M.M., Martins, C.M.G. and Rosa, C.E. (2013): Effects of glyphosate on cholinesterase activity of the mussel Pernaperna and the fish Danio rerio and Jenynsiamultidentata: In vitro studies. Aquat. Toxicol., 130: 171-173.

103.Saravanan, R.; Revathi, K. and Murthy, B. (2008): Lambda cyhalothrin induced alterations in antioxidant enzyme status of various tissues in freshwater catfish Clarias batrachus. Asian J MicrobiolBiotech Environ Sci 10:341-349.

104.Sayeed, I.; Parvez, S.; Pandey, S.; Bin-Hafeez, B.; Haque, R. and Raisud, S. (2003): Oxidative stress biomarkers of exposure to deltamethrin in freshwater fish, Channa punctatus Bloch. Ecotoxicol Environ Saf 56:295-301.

105.Schlenk, D., Handy, R., Steinert, S., Depledge, M.H. and Benson, W. (2008): BiomarkersIn Di Giulio, R.T, Hinton DE, editors. The Toxicology of Fishes. New York: CRC Press: Taylor and Francis Group. pp 683731.

106.Schmieder, p.k., Tapper, M.A., Kolanczyk, R. C., Hammermeister, D.E. and Denny, J. S. (2003): discriminating redox cycling and arylation pathways of reactive chemicals toxicity in trout hepatocytes. ToxicolSci, 72(1): 66-76.

107.Seth, N. and Saxena, K. (2003): Haematological responses in a freshwater fish Channa punctatus due to fevalerate. Bull. Environ. Contam. Toxicol., 71:1192-1199.

108.Shailaja, M. S. and D'Silva, C. (2003): Evaluation of impact of PAH on a tropical fish, Oreochromismossambicus using multiple biomarkers. Chemosphere, 53(8), 835-841.

109.Shaklee, J.B., Champion, M.J. and Whitt, G.S. (1974): Developmental genetics of teleosts—biochemical analysis of lake Chubsucker ontogeny. Dev Biol 38:356-382.

110.Shalaby, A. M., Ramadan, A. A., El Gammal, M. A., El Aganif, E. M. and Ebrahim, M. S. M. (2011): Beneficial using of edta to reduce cadmium toxicity and to improve the physiological and biochemical profiles of catfish ( Clarias gariepinus). Egyptian Journal of Aquaculture, 1(1), 55-69.

111.Sharbidre, A. A; Metkari, V. and Patode, P. (2011): Effect of methyl parathion and chlorpyrifos on certain biomarkers in various tissues of guppy fish, Poeciliareticulata. Pest Biochem Phys 101:132-141.

112.Shenoy, K. A., Somayaji, S. N., and Bairy, K. L. (2002): Hepatoprotective effects of Ginkgo biloba against carbon tetrachloride induced hepatic injury in rats.Indian J. Pharmacol, 33(4):260-266.

113.Shibata, N., and Kobayashi, M. (2008): The role for oxidative stress in neurodegenerative diseases.Brain Nerve, 60(2):157-170.

114.Singh, R.K. and Sharma, B. (1998):Carbofuran-induced biochemical changes in Clarias batrachus. Pest Sci 53:285-290.

115. Tefferi, A., Hanson, C. A. and Inwards, D. J. (2005): How to interpret and pursue an abnormal complete blood cell count in adults. In Mayo Clinic Proceedings (Vol. 80, No. 7, pp. 923-936). Elsevier.

116.Ueno, D.; Inove, S.; Takahashi, S.; Ikeda, K.; Tanaka, H Subramanian, AN, Fillmann, G, Lam, PKS, Zheng, J, Muchtar, M, Prudente, M, Chung, K, Tanabe, S. (2004): Global pollution monitoring of butyltin compounds using skipjack tuna as a bioindicator. Environ, Pollut. 127, 1-12.

117.US EPA, (1997): Registration Eligibility Decision (RED):Pendimethalin.EPA738/R97-007-Office of Prevention, pesticides, and toxic substances. Washington DC, USA.

118.US EPA. (1985): Pesticide Fact Sheet Number 50: Pendimethalin: Office of Pesticides and Toxic Substances. Washington, DC: US EPA. pp 10-116.

119.van der Oost, R., Beyer, J. and Vermeulen, N.P. (2003): Fish bioaccumulation and biomarkers in environmental risk assessment: a review. Environ ToxicolPharmacol 13:57-149.

120.Velisek, J.; Stara, A.; Machova, J. and Svobodová, Z. (2012): Effects long-term exposure to simazine in real concentrations on common carp, (CyprinuscarpioL).Ecotoxicol. Environ. Saf., 76: 79-86. 
121.Velisek, J.; Stastna, K.; Sudova, E.; Turek, J. and Svobodov, Z. (2009): Effects of subchronic simazine exposure on some biometric, biochemical, haematological and histopathological parameters of the common carp, (CyprinuscarpioL). Neuroendocrinol. Lett., 30(suppl.1): 236-241.

122.Velisek, J.; Stara, A.; Kolarova, J. and Svobodova, Z. (2011): Biochemical, physiological and morphological responses in common carp, (CyprinuscarpioL). after long -term exposure to terbutryn in real environmental concentration. Pest. Biochem. Physiol., 100: 305-313.

123.Vutkuru, S. (2005): Acute effects of Hexavalent chromium on survival, oxygen consumption, Hematological parameters and some biochemical profiles of the Indian Major Carp, Labeorohita. InternationalJournal of Environmental Research and Public Health, 2, 456-462.

124.Wedmeyer, G. A. and Wood, J. (1974): Stress a predisposing factor in fish disease, P: 399. U.S. Fish/ Wildlife Service.

125. Widianarko, B. ; Van Gessel., Verwei, CAM, and Van Straalen, N. M. (2000): Association betweentrace metals in sediments, water and guppy,Poecilia reticulate (Peters)., from urban streamsof Semarang, Indonesia.,Ecotox. Environ. Safe. 46, 101-107.

126. Wieland, H., and Seidel, D. (1982): Improved assessment of plasma lipoprotein patterns. IV. Simple preparation of a lyophilized control serum containing intact human plasma lipoproteins. Clinical. chemistry, 28(6):1335-1337.

127.Wilson, R. W. and Taylor, E.W. (1993): The physiological responses of freshwater rainbow trout, Oncorhynchus mykiss, during acutely lethal copper exposure. J Comp Physiol B 163:38-47. doi:10. $1007 / B F 00309663$.

128. Yoshioka, T., Kawada, K., Shimada, T., and Mori, M. (1979): Lipid peroxidation in maternal and cord blood and protective mechanism against activated-oxygen toxicity in the blood.Am. J. Obstet. Gynecol., 135(3):372376.

129.Young, D. S., and Friedman, R. B. (2001): Effects of disease on clinical laboratory tests (Vol. 1).Amer Assn for Clinical Chemistry.

130.Zaahkouk, S. A., Abou-Zeid, M. M., El-Nabarawy, S. K., and El-Zawahry, E. I. (1996): Some haematological and physiological changes induced by certain pesticides to the Nile catfish, Clarias lazera (Claridae). Al-Azhar Bull. Sci. Egypt, 7(1), 799-804. 